\title{
Oligomerization and Conformational Change Turn Monomeric $\beta$-Amyloid and Tau Proteins Toxic: Their Role in Alzheimer's Pathogenesis
}

\author{
Botond Penke ${ }^{1, *}$, Mária Szúcs ${ }^{1}$ and Ferenc Bogár ${ }^{1,2}$ \\ 1 Department of Medical Chemistry, University of Szeged, H-6720 Szeged, Hungary; \\ szucs.maria.1@med.u-szeged.hu (M.S.); bogar@sol.cc.u-szeged.hu (F.B.) \\ 2 MTA-SZTE Biomimetic Systems Research Group, University of Szeged, H-6720 Szeged, Hungary \\ * Correspondence: penke.botond@med.u-szeged.hu
}

Received: 10 March 2020; Accepted: 31 March 2020; Published: 3 April 2020

\begin{abstract}
The structural polymorphism and the physiological and pathophysiological roles of two important proteins, $\beta$-amyloid $(\mathrm{A} \beta)$ and tau, that play a key role in Alzheimer's disease (AD) are reviewed. Recent results demonstrate that monomeric $A \beta$ has important physiological functions. Toxic oligomeric $A \beta$ assemblies (A $\beta \mathrm{Os}$ ) may play a decisive role in $\mathrm{AD}$ pathogenesis. The polymorph fibrillar $A \beta$ (fA $\beta$ ) form has a very ordered cross- $\beta$ structure and is assumed to be non-toxic. Tau monomers also have several important physiological actions; however, their oligomerization leads to toxic oligomers (TauOs). Further polymerization results in probably non-toxic fibrillar structures, among others neurofibrillary tangles (NFTs). Their structure was determined by cryo-electron microscopy at atomic level. Both $\mathrm{A} \beta \mathrm{Os}$ and TauOs may initiate neurodegenerative processes, and their interactions and crosstalk determine the pathophysiological changes in AD. TauOs (perhaps also $\mathrm{A} \beta \mathrm{O}$ ) have prionoid character, and they may be responsible for cell-to-cell spreading of the disease. Both extra- and intracellular $\mathrm{A} \beta \mathrm{Os}$ and TauOs (and not the previously hypothesized amyloid plaques and NFTs) may represent the novel targets of AD drug research.
\end{abstract}

Keywords: Alzheimer's disease; amyloid $\beta$ oligomers; tau oligomers; physiological actions; pathophysiology; amyloid formation; $\mathrm{A} \beta \mathrm{O}-\mathrm{TauO}$ crosstalk; amyloid structure

\section{Introduction}

Alzheimer's disease (AD) is an incurable and progressive neurodegenerative illness. It is characterized with memory loss, behavioral dysfunction, and mostly rapid cognitive decline. AD begins after age 65 (late-onset AD, LOAD) in most cases (90-95\%). In rare cases, AD occurs at a relatively young age $(<65)$ constituting early-onset $\mathrm{AD}$ (EOAD).

Despite more than 30 years of intensive research, the pathophysiology of AD is not completely understood yet. This fact might be the reason why a very large number of complex clinical trials have failed and there is no curative treatment of the disease.

The pathological hallmarks of AD are well-known, the disease has a specific neuro-pathological profile: accumulation of proteinaceous deposits in the brain-amyloid plaques (containing $\beta$-amyloid (A $\beta$ ) peptides) and neurofibrillary tangles (NFTs). More than $80 \%$ of AD patients also show cerebral amyloid angiopathy (CAA) pathology, in which brain $\mathrm{A} \beta$ deposits have been demonstrated in the wall of small-to-medium blood vessels and meninges. AD is also characterized by synaptic dysfunction, neuronal loss, vascular alterations, and astrogliosis [1].

Many hypotheses have been published for explaining the pathology and progress of AD during the last 30 years. We address only the most important and accepted hypotheses: 
1. The acetylcholine hypothesis: loss of cholinergic neurons and neurotransmission causes AD [2].

2. The $\beta$-amyloid cascade hypothesis [3] evolved and changed much over the years: amyloid plaques containing misfolded $A \beta$ play a decisive role in $A D$ pathogenesis. $A \beta$ also drives tau-mediated neurodegeneration. The $A \beta$ oligomer hypothesis represents the modern version of this theory [4].

3. The tau hypothesis [5]: abnormal phosphorylation of tau proteins is in the background of AD progress.

4. The dual cascade hypothesis: cellular processes simultaneously drive tau and A $\beta$ pathology in the cortex [6].

5. The mitochondrial dysfunction hypothesis [7].

6. The neuroinflammation hypothesis [8] emphasizes the role of immune attack in neuronal loss.

7. The vascular dysfunction hypothesis [9] underlines the role of brain circulation and endothelial-mediated processes in AD pathogenesis.

8. Peripheral $A \beta$ hypothesis: $\beta$-amyloid peptides enter the brain from the blood from the periphery [10].

9. The cellular hypothesis [1] represents a complex view of AD pathogenesis, which emphasizes the central role of aging as the major driver of the disease and the participation of different brain cells (microglia, astrocytes, and brain vasculature) in the pathophysiology.

The basic pathophysiology and neuropathology of AD have been widely reviewed [11-16]. Amyloid forming proteins play a crucial role in AD pathogenesis [17]. It has been accepted that brain accumulation of $\mathrm{A} \beta$ peptide and hyperphosphorylated tau protein aggregates may initiate the pathological processes. It was considered that the imbalance between $A \beta$ synthesis and clearance, and thus $\mathrm{A} \beta$ accumulation, initiate $\mathrm{AD}$. Homeostasis disturbances in aging might be the most important factors in AD dementia. As amyloid plaque precedes cortical tau pathology, it was considered that $A \beta$ drives tau-mediated neurodegeneration in AD. There is strong evidence that $A \beta$ and tau aggregation results in toxic assemblies (soluble oligomers), and effective inhibition of the early steps of aggregation might prevent disease progression [18]. It is now generally accepted that these toxic soluble $A \beta$ and tau oligomers play a key role in AD pathogenesis [17,19-21]. Oligomeric A $\beta$ (A $\beta$ Os) and tau (TaOs) proteins may develop into intra- and extracellular assemblies, both forms can trigger AD pathogenesis. It has also been accepted that $A \beta$ oligomers, but not monomers or fibrils, are responsible for the pathophysiological events of $\mathrm{AD}$ [22]. It has been demonstrated very recently that the levels of gene activity changed dramatically as $\mathrm{A} \beta$ and tau accumulated in the brain [23].

Over the last 25 years, many small molecular drugs and neutralizing antibodies have been designed and prepared that decrease the formation of $A \beta$ peptides or bind $A \beta$ and tau fibrils. Some drugs were also clinically tried in the treatment of AD. Until now, all the clinical trials have failed, and interestingly, some of the drugs worsened the cognitive status of AD patients [24]. The failure of $\mathrm{A} \beta$ - and tau-targeting therapies and the presence of amyloid plaques in cognitively healthy persons question the original amyloid cascade hypothesis.

In this review, we summarize the most important results of $\mathrm{AD}$ research, focusing on the physiological role, structure, and toxic effects of different $A \beta$ peptide and tau protein assemblies.

\section{Amyloid Peptides}

\subsection{The Physiological Role of $\beta$-Amyloid Precursor Protein (APP) and the Monomeric A $\beta$ Peptide}

A $\beta$ peptides represent short (37-43 amino acid (AA)) segments of a transmembrane glycoprotein, called the $\beta$-amyloid precursor protein (APP). Recently, several reviews have been published on the structure and the complex physiological functions of APP [25-28].

The processing of APP by proteolytic enzymes $(\alpha-, \beta-$, and $\gamma$-secretases) results in a complex mixture of soluble protein fragments and peptides reviewed in [25]. The main proteolytic cleavage starting by $\alpha$-secretase provides "soluble APP $\alpha$ " (sAPP $\alpha)$ and an 83 AA peptide fragment (non-amyloidogenic 
pathway). The minor, amyloidogenic pathway (the cleavage of APP first with $\beta$ - then with $\gamma$-secretase) results in the formation of "soluble APP $\beta$ " and $\beta$-amyloid peptides of different chain length (37-43 AA). Very recently, cryo-electron microscopy (EM) studies have revealed the structure of $\gamma$-secretase at atomic resolution [29]. This model can be used for explaining the fine details of A $\beta$ formation from APP.

Amyloidogenic cleavage of APP occurs in membranes, where APP, $\beta$-, and $\gamma$-secretases locate together, most probably in the cell membrane and intracellularly in the lysosomes [30]. $\gamma$-secretase is a complex aspartyl protease. Its catalytic subunit (presenilin-1 (PSEN-1) or presenilin-2 (PSEN-2)) contains two aspartyl residues. Mutations in APP as well as PSEN-1 and PSEN-2 genes modulate amyloidogenic cleavage and may influence the production and toxicity of A $\beta$ peptides (see Section 4).

The physiological functions of APP also include cell adhesion, synaptogenetic activity, and control on brain development. APP shows positive neurotrophic effect, plays a crucial role in Wnt signaling, and can function as a receptor [31].

Full length (A $\beta$ 1-40, $A \beta$ 1-42) peptides were considered earlier the most abundant forms in the complex mixture of $\mathrm{A} \beta$ peptides. Very recently, high-resolution mass spectrometry has demonstrated that truncated, shortened peptides are the main $\mathrm{A} \beta$ components in the brain [32]. Altogether, $26 \mathrm{~A} \beta$ proteoforms have been identified from AD brain and cerebrospinal fluid (CSF) [33]. One of the N-terminal truncated forms is the pyroglutamylated peptide, a very toxic A $\beta$ proteoform [34] that may drive $A \beta$ misfolding and aggregation.

Monomeric $\mathrm{A} \beta$ should have important biological functions in low (physiological) concentrations. Evolutionally, the $A \beta$ is a very old (around 500 million years), conserved molecular sequence. All vertebrates have APP and $\beta$-secretase; and the sequence homology between human and other mammalian $A \beta$ is very high (=95\%) [35]. The survival and activity of $A \beta$ during the long evolution process of animals proves that $A \beta$ provides a special advantage for survival of individuals. It was found that depletion of $A \beta$ had bad consequences in animal models and also in humans [36]. A $\beta$ knockout mice survived, but their brain development and neurogenesis were disturbed [37].

Monomeric A $\beta$ peptides may play beneficial roles in human physiology [36] having multiple physiological actions:

1. Regulation of synaptic function by activating nicotinic ACh receptors and participation in memory consolidation. A $\beta$ monomer homeostasis is essential for normal synaptic function [38].

2. Promotion of recovery after traumatic brain injury.

3. Protection of the blood-brain barrier by blocking leaks and preventing leakage.

4. Antimicrobial activity, probably by disturbing membrane structures of microbes.

5. Suppression of tumor growth through inhibition of viruses.

The concentration dependence of the physiological effects of $A \beta$ peptide shows controversial effects: it helps memory consolidation at low (picomolar, physiological) concentrations; however, it inhibits memory at high (pathological) concentrations [39]. As a consequence, A $\beta$ in physiological concentration improves memory. Over a critical concentration (nanomolar range), the monomers start to aggregate to different $\mathrm{A} \beta \mathrm{Os}$ [25]. Several negative clinical experiments with drug candidates (e.g., the failure of $\beta$ - and $\gamma$-secretase inhibitors that decrease $A \beta$ levels) could be explained with the missing neuroprotective effect of monomeric $A \beta$.

\subsection{Formation of $A \beta O$ s and Fibrils by Aggregation}

$\mathrm{A} \beta$ has a molecular lifecycle from monomeric via oligomeric forms to fibrils. $A \beta$ is an intrinsically disordered protein (IDP) lacking a stable 3D structure. IDPs can associate with other molecules and form different fixed structures. The structural "evolution" of A $\beta$ peptides may result in assemblies with growing size shown in Figure 1. 

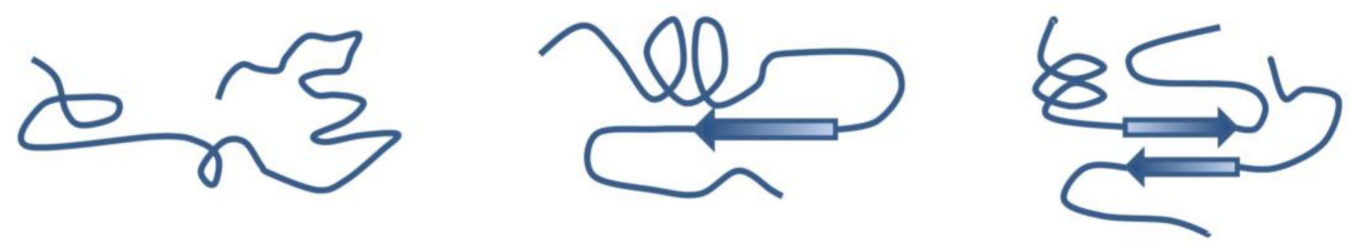

natively unfolded monomer

partially folded monomer

transient small $A \beta O$
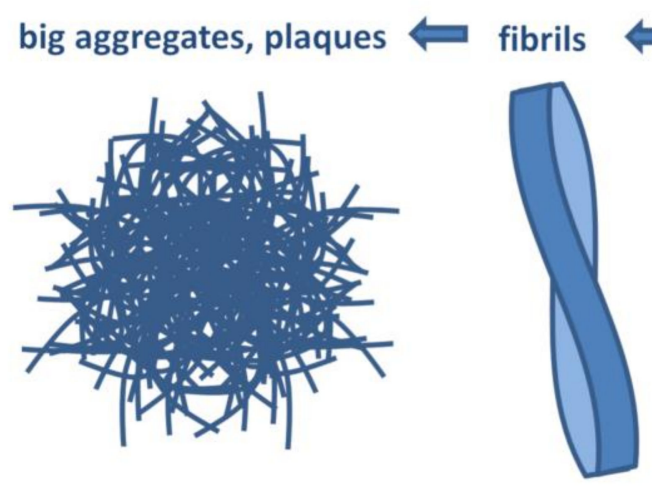

Figure 1. Structural assemblies of $A \beta$ peptides. $A \beta O: A \beta$ oligomer.

The amyloid oligomer hypothesis was first introduced in 1998 and was based on the discovery that fibril-free preparations of $\mathrm{A} \beta \mathrm{O}$ were neurotoxic and could cause neuronal cell death [4].

Since this time, over 4000 scientific papers have been published on $\mathrm{A} \beta \mathrm{O}$, among them more than 400 reviews. Recent reviews by Selkoe and Hardy [19] and Cline et al. [20] give an excellent summary on the development of the $\mathrm{A} \beta \mathrm{O}$ hypothesis.

There is no universal definition for $\mathrm{A} \beta \mathrm{O}$; ; in general, these heterogeneous and transient assemblies contain sub-100-mer aggregates [40].

Many laboratories all over the world have tried to isolate well-defined $\mathrm{A} \beta \mathrm{O}$ s with fixed structure and reproducible pathogenicity. However, it is an almost impossible task owing to the transient nature of $A \beta O s$. Different laboratories gave different names to the oligomeric assemblies of $A \beta 1-40$ and $A \beta$ 1-42 (reviewed by Chiti and Dobson [18]):

- $\quad$ dimers and trimers

- $\quad$ pentamers

- $\quad$ dodecamer $(\mathrm{A} \beta+56)$

- $\quad$ globulomers

- $\quad$ amylospheroids (ASPDs)
- $\quad$ protofibrils (PFs)

- $\quad$ annular protofibrils (APFs)

- $\quad$ amyloid derived diffusible ligand (ADDLs)

- $\quad$ prefibrillar oligomers (PFOs)

- $\quad$ spheric amyloid intermediates

The term of $A \beta$ oligomer can be defined as an assembly of misfolded peptides that maintain the solubility. $\mathrm{A} \beta \mathrm{O}$ s are polymorphic in size: some of them may have very high molecular weight (up to $500 \mathrm{kDa}$ ), and all of them are soluble. None of them have a specific shape, and they never possess cross $-\beta$ structure. Each $A \beta O$ structure represents one of the early intermediates of the amyloid formation pathway [41].

$\mathrm{A} \beta \mathrm{O}$ assemblies can be classified into two groups: toxic and non-toxic subpopulations. There are big differences between the two groups (see Table 1) [42]. 
Table 1. Characterization of the two subpopulations of $A \beta$.

\begin{tabular}{cc}
\hline Toxic Subpopulation & Non-Toxic Subpopulation \\
\hline $\mathrm{Mw}>50 \mathrm{kDa}(\mathrm{HMW}$, high mol. weight) \\
unrelated to plaques & $\mathrm{Mw}<50 \mathrm{kDa}$ (LMW, low mol. weight) \\
no reaction with anti $\mathrm{fA} \beta$ antibody & related to plaques \\
"type 1" $\mathrm{A} \beta \mathrm{O}$ : toxic & binding anti-fA $\beta$ antibody \\
disrupt memory function & "type 2" A $\beta$ O: non-toxic \\
\end{tabular}

$\mathrm{A} \beta \mathrm{O}: \mathrm{A} \beta$ oligomer, $\mathrm{fA} \beta$ : fibrillar $\beta$-amyloid.

The highly toxic oligomers represent only a minority [43] of the heterogeneous $\mathrm{A} \beta \mathrm{O}$ assembly in the human brain [19]. Only an ultrasensitive assay (BioBarcode) can detect the attomolar level of A $\beta O s$ in the CSF of AD patients, where the median level is 30-fold higher than that of healthy humans [44].

Several intrinsic and extrinsic factors may trigger $A \beta$ oligomerization. The $\mathrm{N}$-terminal amino acid sequence has a big influence on self-aggregation of human $A \beta$ into oligomers [45].

$A \beta$ of rodents does not show high propensity for aggregation and formation of $\beta$-folded structures, owing to the differences in three amino acids in the sequence: R5G, Y10F and H13R. Aggregation rate of $A \beta$ is controlled by the $\beta$-content of the monomeric state [46].

Peptide-lipid interactions (e.g., with the ganglioside GM1 or with membrane-lipid rafts) and high $A \beta$ concentration may start $A \beta$ oligomer formation. ER-stress may also cause $A \beta$ aggregation [47]. The hydrophobic surface of amyloid fibrils also catalyzes the formation of highly toxic, $\beta$-sheet-rich $\mathrm{A} \beta \mathrm{O}$ s [48]. It has been demonstrated very recently that aggregatin, a brain protein, may interact with $A \beta$ and facilitates $A \beta$ aggregation [49].

Fibril formation begins with formation of different metastable oligomers [50,51]. Mature A $\beta$ fibrils represent the final stage of fibrillogenesis. More and more evidence demonstrates that truncated $\mathrm{A} \beta$ peptides drive $\mathrm{A} \beta \mathrm{O}$ and fibril formation [34]. The complex process of fibril formation involves primary and secondary nucleation, fibril elongation, and fragmentation. Primary nucleation is a process which begins with the formation of small aggregates (metastable oligomers) from monomers and is continued with growth of fibrils by monomer addition [50-52]. Secondary nucleation is a reaction in which the formation of nuclei is catalyzed by existing seeds (pre-formed aggregates) composed of the same monomers. The effect of in vivo conditions on $A \beta$ aggregation (crowded environment, $\mathrm{pH}$ changes, oxidative stress, presence of carbohydrates, lipids, chaperone proteins, etc.) was excellently reviewed [53].

\subsection{The Structure of $A \beta$ Species}

\subsubsection{Structure of $A \beta$ Monomers and Oligomers}

$A \beta$ monomers have no stable 3D structure, they retain conformational freedom. Monomeric $A \beta$ 1-40 and 1-42 peptides in solution possess very similar Ramachandran-map distribution, which demonstrates a random-coil-like structure [54]. Monomeric A $\beta$ 1-42 may have partly disordered, partly helical structure in apolar solvents [55]. However, it has mostly a $\beta$-sheet structure in neutral aqueous solution [56].

Oligomer formation is largely a hydrophobic collapse. Although the exact structure of the highly bioactive $A \beta O$ is not known yet, theoretical considerations support a $\beta$-sheet-rich conformation with a high number of hydrophobic residues on the oligomer surface ready for membrane interactions. A $\beta O s$ are intermediates between the monomers and fibrils.

Association of the molecules to oligomers results in decreased conformational freedom. Owing to the transient nature of $\mathrm{A} \beta \mathrm{Os}$, many polymorphs exist, and their structure and aggregation grade depend on the experimental conditions. As the number of molecules in the $A \beta O$ Os stabilizes the $\beta$-sheet structure, the average content of $\beta$-sheets increases nearly in parallel with the size of the $\mathrm{A} \beta \mathrm{O}$ [18]. The size of $\mathrm{A} \beta \mathrm{O}$ s that start primary and secondary nucleation in $\mathrm{A} \beta$-fibril formation was 
determined [57]: an $A \beta$ trimer was proved to be the primary and an $A \beta$ dimer the secondary nucleus. In vitro experiments demonstrated that $A \beta 1-42$ forms pentameric and hexameric disks at $4{ }^{\circ} \mathrm{C}$ with very low $\beta$-sheet content [58]. Soluble globular oligomers were formed with mixed parallel and antiparallel $\beta$ sheet structure in the presence of aliphatic detergents [59]. Solid-state and solution NMR studies of $A \beta O$ structure demonstrated that high molecular weight $A \beta O$ s show $\beta$-sheet conformation in the $\mathrm{N}$-terminus of the peptide [60].

\subsubsection{Structure of Fibrillar $A \beta(f A \beta)$}

The structural transition of pathological A $\beta O$ to fibrils has been studied very recently [61] and has been widely reviewed [62]. A $\beta$ fibrils are structurally ordered non-crystalline, water-insoluble substances. Fibrils can be several micrometer long with a width of 10-20 nanometer and are visible in transmission electron microscopy [63]. The fibrils are often twisted.

Fibrils show polymorphism at the molecular level: the same protein may form fibrils of different molecular structure and morphology [18]. Different fibrils may show different toxicity, seeding, and spreading $[27,64]$. Different $A \beta$ structures were found in rapidly progressive and slowly progressive AD brains [65].

The determination of $\mathrm{fA} \beta$ structure has been a challenge owing to its structural polymorphism. Several physicochemical, spectroscopic, and biochemical techniques (solid-state NMR, high-speed atomic force microscopy [66], transition microscopy, Raman and 2D infrared spectroscopy [67], X-ray fiber diffraction, small angle neutron scattering [68,69], cryo-EM) [70] have been used for structural analysis of $\mathrm{A} \beta \mathrm{O}$ s and fibrils. Computational studies have also been used for studying conformational dynamics and stability of different $A \beta$ assemblies [71,72]. These studies demonstrated that $\mathrm{fA} \beta$ s have a cross- $\beta$ structure [73]. Solid-state NMR studies of $A \beta$ peptides showed that dimeric subunits construct the fibrils. A $\beta$ 1-40 monomers have a U-shaped structure stabilized with a salt bridge within the fibrils [74,75]. In A $\beta$ 1-42 fibrils, the monomers possess either an S-shaped [76] or U-shaped [77] structure; the latter is less stable and frequent.

Recently, the subatomic structure of A $\beta$ 1-42 fibrils has been determined by cryo-EM to $4.0 \AA$ resolution (Figure 2) [70]. The fibrils are composed of two intertwined protofilaments, and this structure agrees with the previously reported $A \beta$ structure. Very recently, pure $\beta$-amyloid fibrils have been isolated directly from human AD brain tissue samples, and their structure was studied with cryo-EM [78]. Mass spectrometric analysis of the fibrils showed that the main components had different chain lengths (A $\beta$ 1-40, $A \beta$ 1-38, $A \beta$ 2-40, $A \beta$ 1-37, $A \beta$ 1-36, $A \beta$ 1-39), and the $A \beta$ 1-42 content was low. These brain-derived $A \beta$ fibrils showed multiple fibril morphologies (polymorphy), and all of them had a right-hand twisted structure. In contrast, in vitro formation of $A \beta 1-40$ and $A \beta$ 1-42 fibrils were left-hand twisted. These results underline the priority of the use of brain-derived $A \beta$ samples in structural studies.

\subsection{Mechanisms of Toxicity Induced by AßOs}

In the early experiments, $\mathrm{Li}$ and Selkoe demonstrated that soluble $\mathrm{A} \beta$ fraction extracted from human brain reduced long-term potentiation (LTP) and increased long-term depression (LTD) [79].

Recent data have shown that rather $\mathrm{A} \beta \mathrm{O}$ s than amyloid plaques may play a key role in $\mathrm{AD}$ pathogenesis (reviewed in [21]).

Experiments have proven that $\mathrm{A} \beta \mathrm{O}$ s trigger tau pathology [80], cause oxidative and ER-stress and neuroinflammation [81-91], deterioration of synapses, and neuronal death [92,93]. Figure 3 summarizes the effects of $\mathrm{A} \beta \mathrm{O}$ in $\mathrm{AD}$ neuropathology. 
A

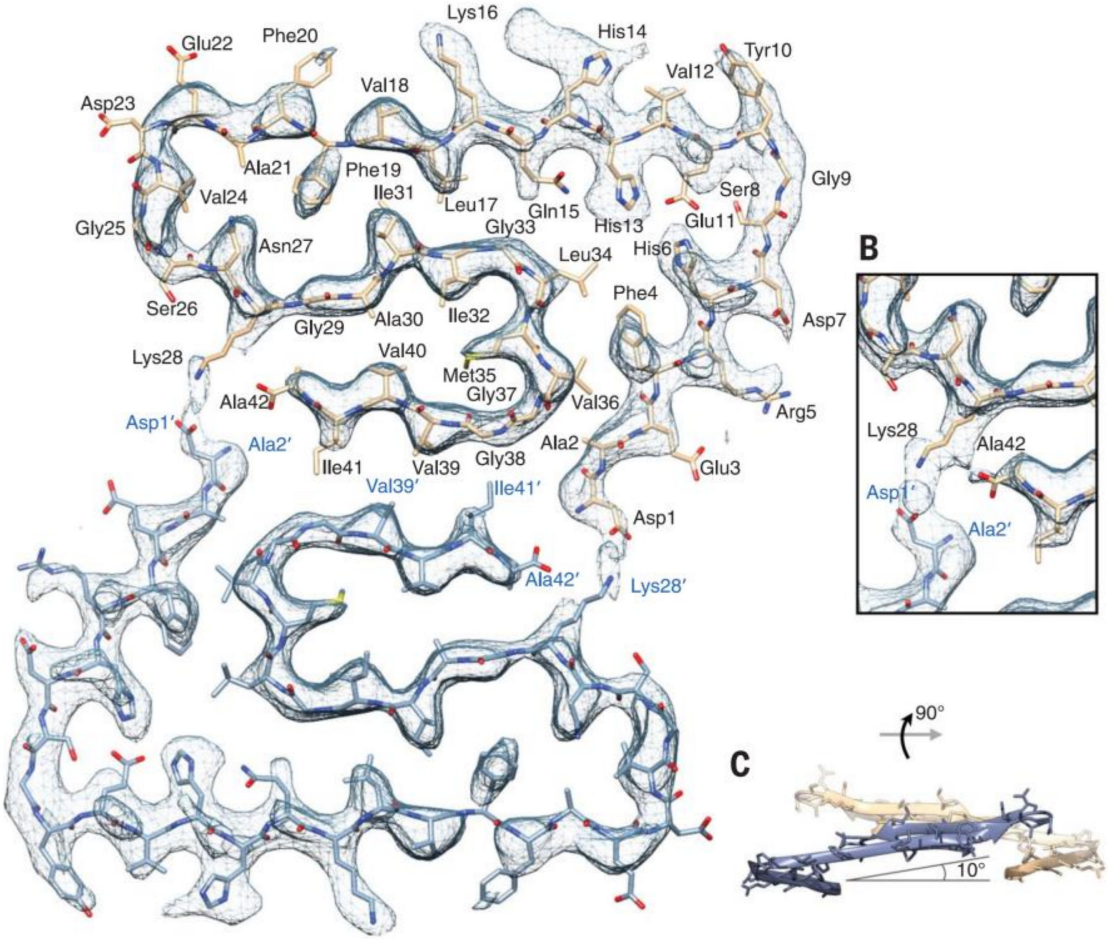

Figure 2. Atomic model and superimposed electron microscopy (EM) density of the A $\beta$ fibril crosssection. (A) Two subunits, one from each protofilament, are shown (blue and brown) together with the masked EM density map (at contour level of $1.5 \sigma$ ). (B) Detailed view of the interactions between the $\mathrm{N}$ - and C-terminus and the sidechain of Lys28 (at contour level of $1 \sigma$ ). (C) Side view of the same two opposing subunits showing the relative orientation of the non-planar subunits. The large peripheral cross- $\beta$ sheet is tilted by $10^{\circ}$ with respect to the plane perpendicular to the fibril axis. From [70]. Reprinted with permission from AAAS.

\section{$\mathrm{Ca}^{2+}$ dyshomeostasis}

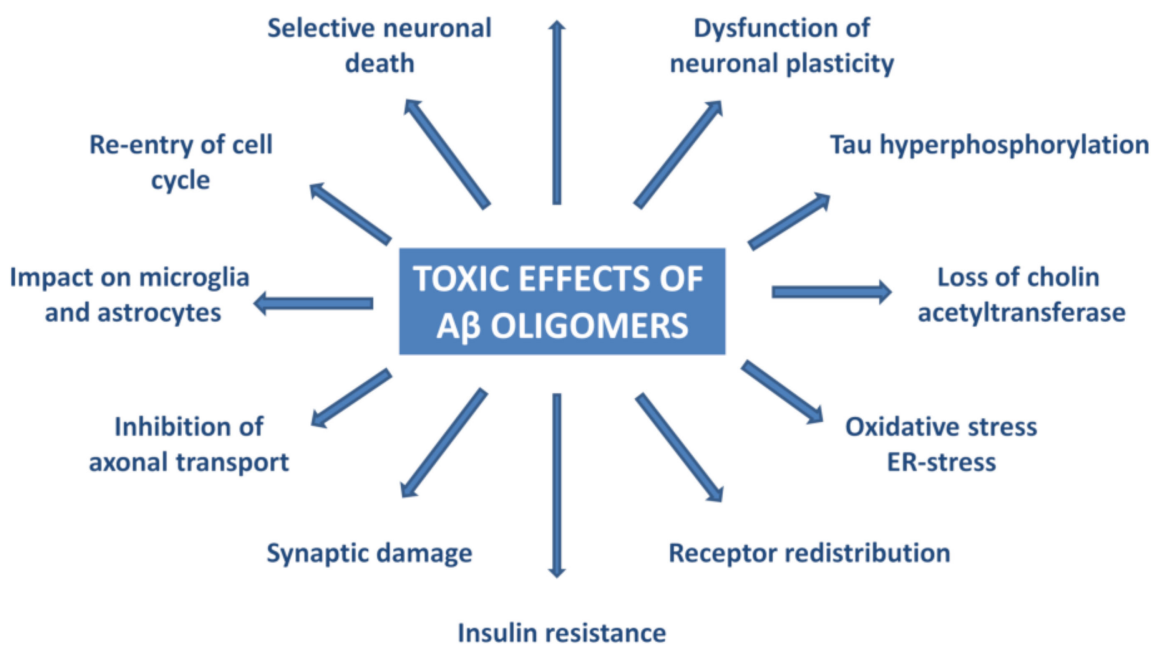

Figure 3. Pathophysiological effects of $A \beta$ oligomers.

$\mathrm{A} \beta \mathrm{O}$ s were observed in the synapses of $\mathrm{AD}$ model mice by high resolution imaging techniques (STORM, immunogold-TEM, FRET) [94]. In humans, the Osaka mutation of APP (E693 deletion) causes accumulation of $\mathrm{A} \beta \mathrm{O}$ and $\mathrm{AD}$ pathology, without senile plaque formation $[85,89,95-97]$. A $\beta \mathrm{O}$-selective 
antibodies prevent AD-like pathology in mice [98-103]. This evidence demonstrates that $\mathrm{A} \beta \mathrm{O}$ is necessary (and also sufficient) for triggering AD-associated neurodegeneration.

Different hypotheses may explain the toxic effect of $A \beta O$ to neurons:

1. The membrane hypothesis focuses on the lipid membrane-A $\beta O$ interactions. $A \beta O$ s can deteriorate membrane structures, insert directly into cell membranes, and may form pores [104] inducing Ca-influx to the cells [104]. The ganglioside GM1 plays a decisive role in the membrane-A $\beta O$ interactions and $\mathrm{A} \beta \mathrm{O}$ toxicity [105].

2. According to the receptor hypothesis, $\mathrm{A} \beta \mathrm{O}$ s are pathogenic ligands that can bind to specific receptors [106-109]. Several facts support this hypothesis:
a. saturation of the binding sites,
b. binding specificity for definite neural cells,
c. targeting of synapses,
d. receptor antagonists inhibit the toxic effect,
e. the binding sites are trypsin sensitive proteins

Thathiah and De Strooper published that 22 G-protein coupled receptors are involved in the pathogenesis of AD [110]. Godoy in 2014 showed five anti-aging signaling pathways (Wnt, 5' AMPK, mTOR, Sirt1, and PGC-1alpha) that have a crosstalk in AD [111]. It is widely accepted that A $\beta O s$ interact with several putative receptors at the excitatory synapses and thereby stimulate intracellular signaling pathways resulting in LTP inhibition and facilitation and finally synapse loss.

$\mathrm{Up}$ to now, a huge number of candidate $\mathrm{A} \beta \mathrm{O}$ receptors and binding proteins have been published (reviewed in [20]). Some of them are considered to directly bind $\mathrm{A} \beta \mathrm{O}$ :

- Cellular prion protein (PrPc)

- $\quad \mathrm{Na}, \mathrm{K}-\mathrm{ATPase}$ alpha 3 subunit (NKAa3)

- RAGE receptor

- Tyrosine kinase ephrin type A receptor

- Tyrosine kinase ephrin type B receptor

- p75 neurotrophin receptor

- leucocyte immunoglobulin receptor B2 (LILRB2)

- $\quad$ triggering receptor expressed on myeloid cells 2 (TREM2)

- $\quad$ toll-like receptor 2 (TLR2R)

- neuroligin

A large group of proteins indirectly participate in the toxic effect of $\mathrm{A} \beta \mathrm{O}$ :

- NMDA receptors

- $\quad$ AMPA receptors

- metabotropic Glu receptor 5

- frizzled receptor [112]

- alpha7nACh receptor

- adrenergic receptors

- calcium channels

- $\quad \mathrm{N}$-formyl peptide receptor 2

- $\quad$ IgGFc region receptor II b

- Transient receptor potential melastatin (TRPM2)

- insulin receptor

- Wnt receptor 
A $\beta$ Os also bind to synaptic proteins, such as synGap and Shank3 in the postsynaptic density (PSD), and these interactions may disturb the ordered structure of PSD [113].

It is not clear why there are so many receptor candidates for $A \beta O$ s. It is suggested that not all of the above-mentioned proteins are genuine receptors for $A \beta$. A $\beta$ Os can associate with many proteins owing to their IDP structure. Indeed, very recently, a systematic study of $15 \mathrm{~A} \beta \mathrm{O}$ receptor candidates revealed that only three of them (PrPc, LilrB1, and neuroligin receptor 1 ) show specific binding to A $\beta O$ [114]. PrPc and NgR1 preferentially bind synaptotoxic A $\beta$ species, also in the brain of AD patients.

However, the main question of $\mathrm{A} \beta \mathrm{O}$-receptor interactions remains unanswered: how do these interactions cause cellular damage, and what is the mechanism of signal transduction? These mechanisms have been successfully analyzed in several cases.

The best known example is the $\operatorname{PrPc}-\mathrm{A} \beta \mathrm{O}$ interaction and the subsequent signalization cascade [115-117]. The simplified pathway is the following (Figure 4): A $\beta O$ binds to PrPc, then stimulates the Proto-oncogene tyrosine-protein kinase Fyn by activating the metabotropic GluR5. Within the cell, Fyn can phosphorylate tau protein and also triggers the phosphorylation of the NR2B subunit of NMDA receptors, which activates Ca-influx. Taken together, the activation of the A $\beta O-P r P c$ pathway has the following downstream consequences: $\mathrm{Ca}^{2+}$ dyshomeostasis, tau hyperphosphorylation, and synaptic dysfunction and loss.

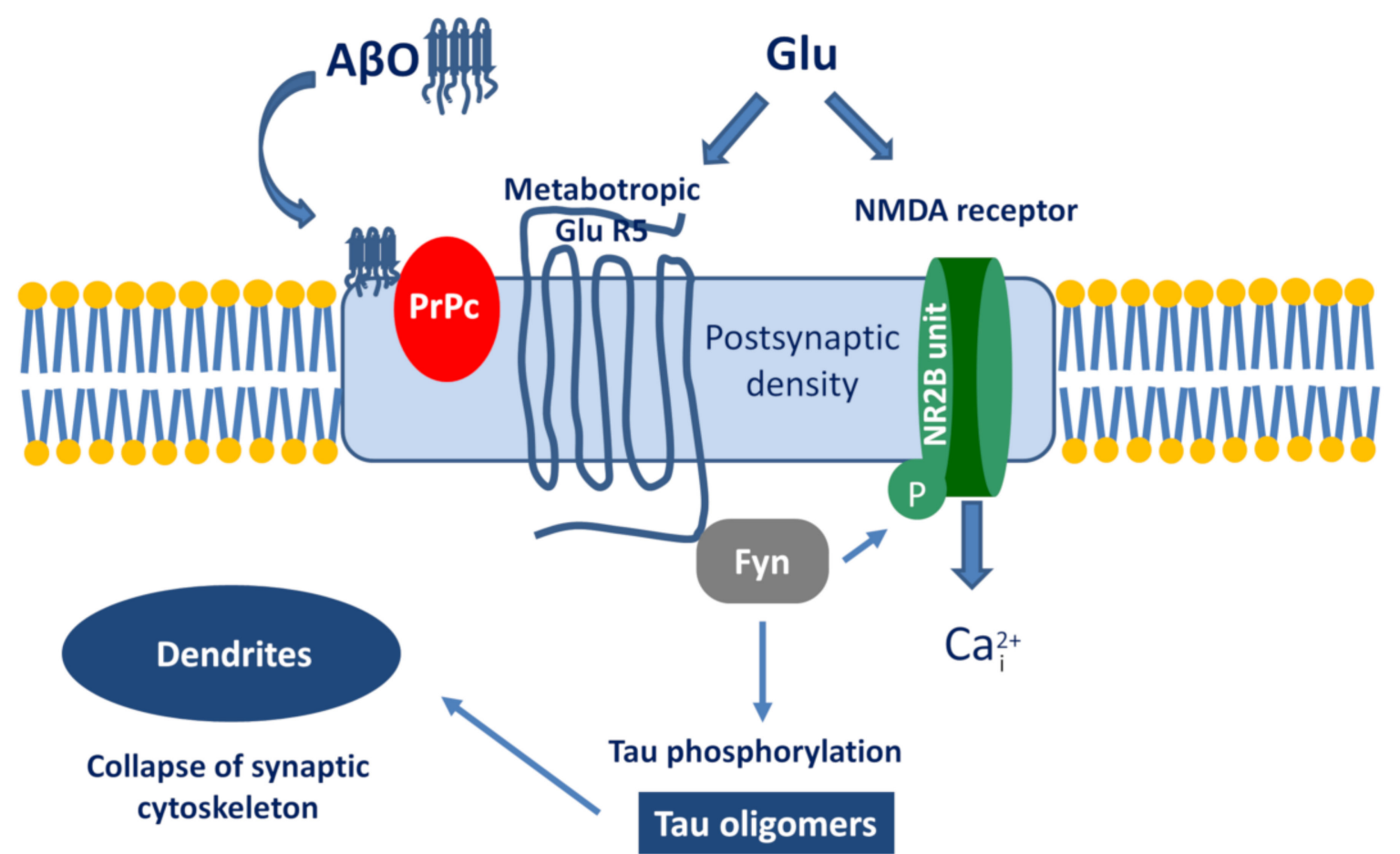

Figure 4. The signalization cascade initiated by the interaction between $A \beta$ oligomer $(A \beta O)$ and prion protein $(\mathrm{PrPc})$.

A detailed analysis was also performed on how the NKAa3-A $\beta \mathrm{O}$ binding may cause neuronal damage [118]. It was demonstrated that signal transduction starts with a stepwise decrease of ATPase activity. A $\beta O$ s initiate the restructuring of NKAa3 and formation of toxic membrane clusters with participation of different other proteins in the dendritic spines. Finally, Ca dyshomeostasis in the cell may cause mitochondrial dysfunction and apoptosis [119]. Very recent results support the hypothesis that inhibition of NKAa3 by A $\beta$ Os starts the early stages of AD [113].

Recent experiments demonstrated that neuroligin R1 may also be a specific receptor for $A \beta O$, although the binding affinity is low [114]. Very recent studies shed light on the possible role of adrenergic receptors: $\mathrm{A} \beta \mathrm{O}$ can bind to an allosteric site of the alpha2A receptor. This binding changes 
norepinephrine signaling and activates glycogen synthase kinase $3 \beta$ (GSK3 $\beta$ ), thereby triggering tau hyperphosphorylation [120].

Recently, the role of $A \beta O$ in alterations of Glu-ergic signaling and cognitive decline during the progress of $\mathrm{AD}$ has been reviewed [121]. At the early stage of $\mathrm{AD}, \mathrm{A} \beta \mathrm{O}$ s upregulate tripatrite Glu-ergic synapses and thus increase Glu signaling forming excitotoxic environment around the neurons. The hypoactivation and cognitive decline in the later stage of $\mathrm{AD}$ are probably due to increasing neural loss.

It has been found very recently that the toll-like receptor 2 behaves as a primary receptor for $\mathrm{A} \beta \mathrm{O}$ and triggers the process of neuroinflammation [122]. Similarly, it was demonstrated that TREM2 (the triggering receptor expressed on myeloid cells 2) directly binds $\mathrm{A} \beta \mathrm{O}$ s in nanomolar affinity and modulates microglial formation [123]. Certain nuclear receptors, such as the vitamin D receptors, are also linked to $\mathrm{A} \beta \mathrm{O}$ toxicity and $\mathrm{AD}$ pathology [124].

In conclusion, several receptors might be involved in the mediation of $\mathrm{A} \beta \mathrm{O}$ cytotoxicity in $\mathrm{AD}$. It is proposed that the signalizations started by PrPc, NKAa3, TREM2, the glutamate, and ephrin receptors may play a decisive role in starting the pathophysiological processes.

\subsection{Intracellular $A \beta$ and Extracellular Plaques}

It was found long ago that $A \beta$ can form intracytosolic and intranuclear aggregates $[125,126]$. Early intracellular accumulation of $\mathrm{A} \beta$ (iA $\beta$ ) was considered a key event of neurodegeneration, which predicts synaptic dysfunction [127].

It has been a controversial scientific debate on the origin and role of iA $\beta$. There are alternate sources for iA $\beta$ formation. $\mathrm{A} A \beta$ immunoreactivity was observed in neurons by light and fluorescence microscopy and immuno-EM during the life span of Down syndrome patients [128]. It can be formed within the cells. In addition, a part of iA $\beta$ may originate from extracellular sources entering the cells by receptor mediated internalization [127]. According to a very recent hypothesis, fast aggregation of long $\mathrm{A} \beta \mathrm{s}$ (43 to $52 \mathrm{AA}$ residues) is the main component of the iA $\beta$ assemblies [129]. Subcellularly, the endoplasmic reticulum-intermediate compartment and the endosomal-lysosomal system participate in iA $\beta$ generation $[130,131]$.

More and more evidence demonstrates that $i A \beta$ is responsible for early synaptic dysfunction and neuronal loss, plaque formation and cognitive impairment; in other words, iA $\beta$ is the toxic $A \beta$ species [128]. It was demonstrated by immunochemistry that iA $\beta$ is able to form NFTs [132]. Accumulation of iA $\beta$ precedes tau hyperphosphorylation and is associated with microtubular degeneration. Mitochondria isolated from the brains of AD patients or AD mouse model animals contained iA $\beta$. It is localized in the inner mitochondrial membranes and cristae [127]. Immuno-EM experiments explained the role of $\mathrm{iA} \beta$ in plaque formation: plaques originate from degenerating neurites [128]. Activated microglia also plays an important role in the formation of amyloid plaques [128]. Very recent experimental data have also revealed that aggregated iA $\beta$ co-localized mostly with mitochondria and endosomes and much less with lysosomes in a 3xTg mouse model of $\mathrm{AD}$ [129]. Overexpression of $\mathrm{A} \beta$ and $\mathrm{iA} \beta$ formation causes different mitochondrial dysfunctions (inner transport, axonal transport of mitochondria, and depletion in the synapses) [133]. iA $\beta$ s may serve as a template showing intracellularly a prion-like seeding in N2A cell cultures [134].

The role of extracellular $A \beta$ plaques in $A D$ pathophysiology has been discussed for a long time. Plaques have been the main target of AD drugs, but plaque-decreasing therapies have failed. Recently, plaques are increasingly viewed as tombstones [128]. Immuno-EM experiments explained the role of $\mathrm{iA} \beta$ in plaque formation: plaques originate from degenerating neurites [128]. Activated microglia plays also important role in formation of amyloid plaques [135]. Very recently, the nanoscale structure of plaques has been thoroughly studied [136]. The combination of two different 3D superresolution methods (array tomography (AT), and stimulated emission depletion microscopy (STED)) have been used for studying plaques in human $\mathrm{AD}$ brain tissues. It was observed that human amyloid plaques had a dense core of highly ordered $A \beta$ structure $(f A \beta)$ surrounded by a peripheral halo of medium and 
small size of $A \beta$ species. The latter diffusible, toxic $A \beta O$ components of the halo may be responsible for the observed axonal degeneration in the neighborhood of the plaques.

$\mathrm{A} \beta$ also deposits intraneuronally as neurofibrillary tangles and also in blood vessels [137]. The structure and composition of amyloid deposits in the wall of blood vessels of CAA patients were studied by mass spectrometry very recently [138]. It was found that the molecular composition of A $\beta$ deposits in blood vessels (mostly 1-40 and 2-40) are different to parenchymal deposits of AD patients (typically $A \beta 1-42$, $A \beta 2-42$, pGlu $A \beta 3-42$, pGlu $A \beta$ 11-42).

\section{Tau Proteins}

TauOs and tau filaments may play a decisive role in the pathogenesis of AD and other tauopathies. Experimental studies have revealed the decisive role of TauOs in the pathogenesis of AD in the last ten years.

\subsection{Tau Isoforms, Domain Structure, Post-Translational Modifications}

The role of tau proteins in neurons was re-evaluated and excellently reviewed very recently [138-140]. Tau belongs to the family of microtubule-associated proteins (MAPs) that occur in brain cells. Alternative splicing of the human microtubule-associated protein gene (MAPT) product provides six tau isoforms ranging from 352 to $451 \mathrm{AA}$ (Table 2).

Table 2. Isoforms of the tau protein.

\begin{tabular}{|c|c|c|c|c|}
\hline Name & $\begin{array}{c}\text { MW } \\
\text { (kDa) }\end{array}$ & Length (AA) & & \\
\hline h tau 40 & 45.9 & 441 & 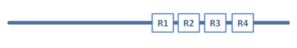 & \multirow{2}{*}{$4 R$} \\
\hline $\mathrm{h}$ tau 34 & 43.0 & 412 & C 一 & \\
\hline h tau 24 & 40.0 & 383 & $\longrightarrow$ - & \multirow{4}{*}{$3 R$} \\
\hline h tau 39 & 42.6 & 410 & 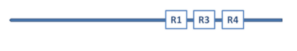 & \\
\hline $\mathrm{h}$ tau 37 & 39.7 & 381 & $\longrightarrow$-R1 $-R 3-\sqrt[R 4]{R 4}$ & \\
\hline h tau 23 & 36.7 & 352 & $\longrightarrow{ }_{R 1}-R_{R 3}-\sqrt{R 4}-$ & \\
\hline
\end{tabular}

There are two subfamilies of tau proteins: the three-repeat (3R) and the four-repeat (4R) groups, which possess three or four repeat domains. (Each repeat domain contains 18-amino acid sequences and is bound together by inter-repeat regions.) Tau proteins have important biological functions; their microtubule stabilizing role has been studied for a long time. A correct tau isoform ratio is necessary for maintaining brain cell homeostasis and preventing neurodegenerative diseases [141]. The repeat regions (together with short joining sequences) are the microtubule binding domain of tau. $\mathrm{N}$-terminal truncation occurs at early stage of $\mathrm{AD}$ and provides a toxic 20-22 $\mathrm{kDa}$ tau fragment [142].

Tau proteins show a large number of post-translational modifications (PTMs) [142] (see Figure 5). PTMs may occur under both physiological and pathophysiological conditions. Phosphorylation occurs on the potential phosphorylation sites: the hydroxyl groups of serine (45 residues), threonine (35 residues), and tyrosine (5 residues). Acetylation, ubiquitylation, and sumoylation are enzymatic processes targeting one of the lysine residues of the $40 \mathrm{in}$ tau and regulate tau activities and degradation. O-glycosylation occurs on Ser and Thr residues. Mostly, N-acetyl glucosamine is attached to tau. Only hyperphosphorylated tau can be N-glycosylated. Nitration of Tyr residues to 3-nitro tyrosine is mediated by reactive nitrogen species. Methylation of Arg and Lys residues is catalyzed by the enzyme methyl transferase and regulates tau metabolism competing with ubiquitylation. Glycation requires no enzyme catalysis. Carbohydrates are coupled covalently to tau in a pathological process leading to the formation of advanced glycation products, causing pathological consequences and neuronal death. It is assumed that PTMs mediate the structural diversity of different tauopathy strains [143]. 


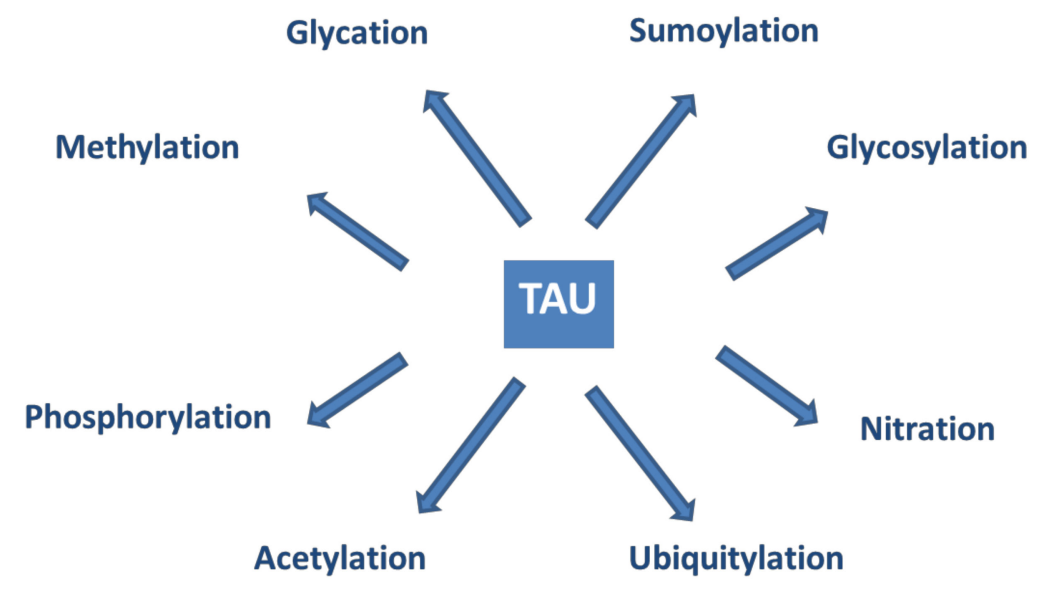

Figure 5. Post-translational modifications of tau proteins.

Tau phosphorylation has been extensively studied as it changes the biological actions of the protein. Tau binds microtubules (MT) via special binding sites (3R and 4R domains). Up to now, at least 31 physiological phosphorylation sites have been identified. Phosphorylation of other sites (e.g., Ser 235, Ser 262, Ser 293, Ser 324, Ser 356, and Thr 231) may result in pathological hyperphosphorylated products. (The term hyperphosphorylation was introduced to distinguish between the normal and pathophysiological phosphorylations). It has been widely accepted that hyperphosphorylation decreases the binding of tau to MTs [144-146]. Several protein kinases can phosphorylate tau (e.g., GSK3 $\beta$, DYRK1A, Fyn), and the phosphate groups can be cleaved by phosphatases (PP1, PP2A, PP2B). The fine balance between the kinase and phosphatase activities determines the phosphorylation state and biological activity of tau proteins.

Recent studies on familial AD patients have shown that the site-specific phosphorylation state of tau changes in different periods of disease progression [147]. Some sites are phosphorylated (e.g., formation of pTau217 and pTau181) as early as two decades before the development of aggregated tau-pathology. Others (e.g., pTau205) increase in parallel with brain atrophy and hypometabolism closer to the onset of AD symptoms. Further studies of the characteristic tau signature may facilitate the evaluation of the results of tau-targeted clinical trials.

\subsection{Physiological Actions of Tau}

Tau is a multifunctional protein that plays a role in basic physiological processes. Unexpectedly, tau deletion in mice does not cause big changes in the phenotype of the animals [148], although aged tau knock-out mice show synaptic loss and brain atrophy $[149,150]$. It is likely that young tau knock-out mice were protected against excitotoxicity by the accumulation of Syn-GAP1 [151,152].

The complex role of tau in health and disease has been reviewed by Naseri et al. [153]. Tau proteins have the following physiological functions:

Protection of DNA. Maintaining the integrity of the genetic material of neurons is highly important, owing to the longevity of this type of cells. Heat shock and oxidative stress cause tau-dephosphorylation and translocation into the nucleus [154]. Heat shock increases the tau-DNA interaction. Tau proteins bind mainly to the AT-rich regions of DNA.

Modulation of NMDAR signaling. Tau is involved in neurotransmission: It binds to Src-kinases, such as Fyn within the neurons [155]. Tau-Fyn interaction is required for NMDAR activation: Fyn- catalyzed phosphorylation of the NR2B subunits starts signaling [156]. Tau modulates signal transduction via modulating the function of presynaptic mitochondria that influence intracellular ATP and Ca-level [157].

The role of tau in MT stabilization and spatial organization has been thoroughly studied [158-160]. Tau plays a pivotal role in MT stabilization: it binds transiently to the C-terminal end of tubulin and drives polymerization of the protein to MTs $[140,161,162]$. Tau phosphorylation regulates tubulin 
binding to MTs $[163,164]$. According to a new hypothesis, tau is not an MT stabilizer, rather it increases the accessibility of long, labile domains for other stabilizer molecules [165].

Phosphorylation of specific binding sites (see Section 3.1) leads to dissociation of tau from MTs and oligomerization to toxic assemblies [166]. The precise mechanisms of tau-MT interactions (association and dissociation) have been intensively studied. The newest cryo-EM results provided a good model for the tau-tubulin binding [167].

Axonal transport regulation. In vitro studies demonstrate that tau modulates the motility of motor proteins in a concentration- and isoform-dependent manner [168]. Tau overexpression decreases the axonal transport of subcellular organelles, such as mitochondria [169].

Interaction with the cytoskeleton. Tau directly interacts with spectrin, an important cytoskeletal protein and thus regulates the shape of cells $[170,171]$. Tau interaction with the actin cytoskeleton results in the formation of actin filaments and bundles [172].

Tau as a signaling molecule. Regulation of the brain insulin signalization pathway is a novel role of tau $[173,174]$. Tau may control hippocampal plasticity via this pathway.

Native tau is involved in normal synaptic activity in the PSD [175]. In vivo observations demonstrate that native tau plays a role in dendritic development [139].

\subsection{The Structure of Tau Oligomers and Fibrils}

Tau in monomeric form is a highly soluble, intrinsically disordered protein with an open structure. A maximum of $10 \%$ of the protein sequence possesses any kind of ordered structure [176]. The native tau has only a low tendency for aggregation [177]. Free sulfhydryl groups in tau increase the predisposition for polymerization of the monomer. This is a multistep chemical process that shows different stages as reviewed in [141] (Table 3). According to the newest hypothesis, diffusible TauOs are toxic, but larger polymers probably are non-toxic assemblies [174].

Table 3. Classification and toxicity of tau oligomers and fibrils [174].

\begin{tabular}{ccc}
\hline Name & Size & Toxicity \\
\hline Tau monomers & $67-70 \mathrm{kDa}(352-441 \mathrm{AA})$ & non-toxic \\
toxic \\
Tau dimer-trimer & $67-70 \mathrm{kDa}$ & toxic \\
Abnormally phosphorylated monomer & $120-180 \mathrm{kDa}$ & toxic \\
Small soluble oligomers (TauOs, 6-8 units) & $300-500 \mathrm{kDa}$ & toxic \\
Granular tau oligomers (gTauOs, 36 units) & $1800 \mathrm{kDa}$ & not always toxic \\
Straight filaments (SFs) & $50 \mathrm{~nm} \times 10 \mathrm{~nm}$ & probably non-toxic \\
Paired helical filaments (PHFs) & $80 \mathrm{~nm} \times 10-20 \mathrm{~nm}$ & probably non-toxic \\
Neurofibrillary tangles (NFTs) & & probably non-toxic \\
\hline
\end{tabular}

TauOs have an increasingly ordered structure ( $\beta$-sheet). The exact mechanism of TauO formation is not yet known [178]. Model peptide experiments emphasize the role of membranes in oligomerization [179]. There is an assumption that granular tau oligomers (gTauO) might be the most toxic species, this type of tau could be isolated from AD brain [139]. It is important that gTauOs are present in the brain at very early stages of $A D$, prior any cognitive symptoms [180]. It was hypothesized that $A \beta$ assemblies catalyze tau aggregation by a cross-seeding mechanism [181].

Tau fibrils form intracellular deposits (e.g., NFTs). The determination of the structure of tau fibrils (straight filaments and PHFs) at atomic level by cryo-EM represents a real breakthrough in the field. Fitzpatrick isolated tau amyloid fibrils (both straight and paired helical filaments) from an AD brain and analyzed the conformation by cryo-EM (Figure 6). At $3.4 \AA$ A resolution, tau in NFTs is aberrantly misfolded and hyperphosphorylated [182]. The ultrastructural level of the two filaments were a little different but had a common element: C-shaped monomers formed $\beta$-sheet conformation, and the cores of both fibrils contain this $\beta$-sheet motif. Filaments are formed primarily from R3 and R4 repeat regions of tau. The filaments from Pick's disease brain [183] contained only three R tau domains. Filaments 
were also isolated from chronic traumatic brain encephalopathy brains [184], and the structure was determined at $2.3 \AA$ resolution. 3R and 4R domains form the ordered core structures that contain a hydrophobic cavity in these tau filaments. These results show that tau have different phosphorylation stages and form distinct conformers in different neurodegenerative diseases. Very recently, it was demonstrated that PTMs mediate the structural diversity of distinct tauopathy strains [143].
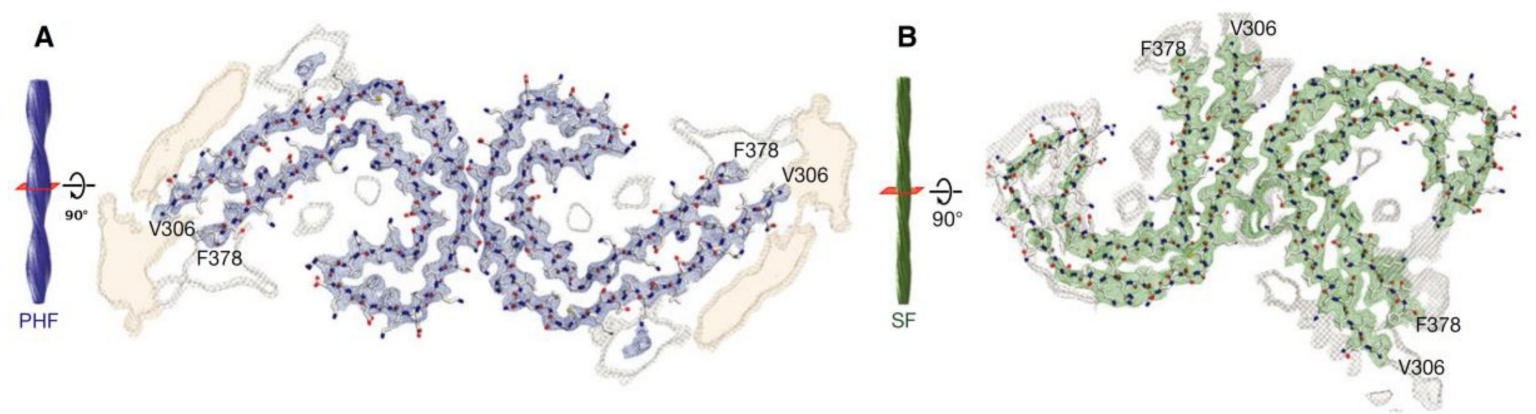

Figure 6. Cross-sections of paired helical and straight tau filament core structures from Alzheimer's disease. Cryo-EM density and atomic models of paired helical (A) and straight (B) tau filaments. Sharpened, high-resolution maps are shown in blue (paired helical filaments) and green (straight filaments). Paired helical and straight filaments are ultrastructural polymorphs. Their protofilament corresponds to residues V306-F378 of tau (R3 + R4 + 10 amino acids carboxy-terminal to the repeats). Unsharpened densities are shown in orange and grey. From [185]. Reprinted with permission from the publisher (John Wiley \& Sons, Inc.).

\subsection{Pathophysiological Effects of Tau Assemblies.}

The view on the role of different tau assemblies in AD pathogenesis has changed very similarly to the stepwise changing of the $\mathrm{A} \beta$ hypothesis. By now, it has been widely accepted that the big tau assemblies (straight filaments, PHF, NFT, and ghost tangles) are the less toxic tau forms, and rather the smaller, diffusible oligomers are involved in AD pathogenesis [174]. Synaptic dysfunction and loss, as well as axonal transport disturbances, are linked to TauOs and not to NFTs, although tau fibrils may physically hinder transport processes within the cells. The level of cognitive decline and synaptic and neuronal loss in AD is most closely correlated with tau pathology. PET imaging using flortaucipir labeling of brain-tau in AD patients demonstrated that tau is concentrated precisely where brain atrophy is most severe [186].

Several pathophysiological actions of TauO have been observed:

Disaggregation of microtubules. Different pathological conditions (e.g., A $\beta O$ accumulation, GSK3 $\beta$ activation) cause tau modifications (e.g., hyperphosphorylation) and formation of soluble oligomers. As a result, tau dissociates from the MTs (Section 3.2). The structure of MT collapses, and tau may simultaneously translocate to synapses. The details of tau-microtubule interactions, the dynamism of adsorption-desorption (detachment) processes, has been analyzed very recently [160]. Big tau aggregates may be involved in axonal transport defects, causing a direct physical blockade of the transport [187].

Loss of DNA protection. TauOs are not able to enter the cell nucleus, and thus, they cannot protect nuclear DNA [188].

Pathological tau species may impair the transport of nucleocytoplasma [189].

Increased excitability of neurons. Toxic TauOs modulate the neuronal activity and increase their excitability. AD is characterized by epileptic seizures [190]. Administration of tau antisense RNA to AD mice reduce TauO formation and decrease the high mortality of the animals [191,192].

Synaptic loss and disturbing neural circuits. Stable TauO aggregates may accumulate in huge amount in cortical synapses (observed in brightfield microscopy) [193]. Dendritic tau disrupts the synaptic 
cytoskeleton [194] and causes synaptic dysfunction and loss. TauO suppressed and silenced many neurons and impaired the integrity of neural circuits in APPxPS1 mice [195].

Neuroinflammation. Studies on human brains demonstrated that Tau can be involved in microglia activation and, thus, in neuroinflammation [196]. Tau pathology is associated with chronic neuroinflammation, and microglia may phagocyte the pathological dysfunctioning synapses in tauopathic brain [197].

Cell-to-cell spreading. Synaptic tau is a transmissible pathogen: TauOs may disseminate the misfolded tau after templated propagation by cell-to-cell spreading along the anatomical connections. It was observed recently that tau propagation may occur via exosomes [198]. Microvesicles or ectosomes might be also involved in tau spreading [199]. The mechanisms of the propagation of tau in cellular and animal models of diseases have been recently reviewed [200]. No possible receptors have been found that facilitate tau internalization, rather it occurs via macropinocytosis.

According to several authors, AD might be an infectious disease within the living brain [201]. Very recent observations support the cell-to-cell spreading of pathological tau, however, exclude the behavior of TauOs as infectious agents in cell cultures and animal models [202]. Clinical studies demonstrated that tau pathology spreads hierarchically throughout the cortex, and higher network connectivity increases tau propagation [203].

\section{Genetic Risk Factors of AD: Classical Studies and Novel Results}

The genetic risk of $\mathrm{AD}$ should be reconsidered after understanding the physiological and pathophysiological role of $\mathrm{A} \beta \mathrm{O}$ and $\mathrm{TauO}$. The genetic background of familial, autosomal dominant $\mathrm{AD}$ (ADAD, a subset of EOAD) is well established. Overproduction of $\mathrm{A} \beta$ peptides and its decreased clearance augment $A \beta$ level in the brain, and $A \beta$-aggregation and formation of toxic $\mathrm{A} \beta \mathrm{O}$ occur over a critical concentration. ADAD is linked to mutations within the APP and PS1 genes [204]. The mechanisms by which these mutations are coupled to AD have been reviewed [18]. The effects of pathogenic and non-pathogenic mutations of the A $\beta$-sequence within the APP have been studied, and eight important mutation sites were found [25]. Several mutations (e.g., A02V) induce $\mathrm{A} \beta$ overproduction by modulating APP processing, causing amyloid formation and early onset dementia [205]. Interestingly, the so-called Icelander mutation in the same site of the sequence reduces APP cleavage to $A \beta$, and thus, A02T proved to be a non-pathogenic, protective mutation [206].

Several mutations modulate the conformational stability, and thus, the toxicity of $A \beta$. The English APP mutation (H06R) is pathogenic as the peptide may operate as a seed for oligomerization and formation of toxic $\beta$-structure [207].The Flemish (A21G), Dutch (E22Q), Italian (E22K), and Iowa $(\mathrm{D} 23 \mathrm{~N})$ mutations occur in the central hydrophobic core region of $\mathrm{A} \beta$ and affect the conformation stability of $A \beta$ by modulating salt-bridge formation between Asp22 and Lys28 [25].

The Flemish, Dutch, and Italian mutations cause presenile dementia and cerebral hemorrhage. The Iowa and Piedmont (L34V) mutations are associated with dementia and CAA [208]. Until now, a lot of coding mutations have been found in the APP gene. Most of them are pathogenic and cause ADAD. However, these autosomal dominant hereditary disease variants represent only $0.5 \%$ of AD cases and cannot explain the genetic background of LOAD.

The genetic background of LOAD is much more complicated. Although epidemic studies show that about $65 \%$ of a person's risk for $\mathrm{AD}$ is genetically determined, until now only a few dozen $\mathrm{AD}$ risk genes have been identified. Theoretical considerations reveal that there could be hundreds of additional genetic variants, each of which contributing in a small but significant way to AD risk.

Apolipoprotein E (ApoE) is the strongest risk factor for LOAD [209]. This protein binds lipids and transports them to target sites. The APOE gene has three major alleles $(\varepsilon 2, \varepsilon 3$, and $\varepsilon 4)$, the proteins differ from each other by one or two amino acids. The allele frequencies are different: $\sim 7,79$ and $14 \%$ for $\varepsilon 2, \varepsilon 3$, and $\varepsilon 4$, respectively. The APOE status is predictive for late onset AD [210], approximately $40 \%$ to $65 \%$ of LOAD patients have at least one APOE $\varepsilon 4$ allele. ApoE proteins regulate AD risk in different pathways [16]: 
a) $\mathrm{A} \beta$-dependent pathways (reviewed in [210]). ApoE proteins interact with $\mathrm{A} \beta$ by an isoform-specific efficacy (ApoE2 > ApoE3 > ApoE4). ApoE4 supports A $\beta$ aggregation and deposition [211]. ApoE indirectly regulates $A \beta$ clearance by competitive binding to $A \beta$-receptors, e.g., LRP1.

b) ApoE also modulates tau pathology; especially ApoE4 enhances tau pathogenicity.

c) ApoE4 mediates AD risk by modulation of immune and microglial responses to amyloid plaques.

d) ApoE4 has direct pathological effects on neurons and neuronal networks. ApoE3 expressions in neurons are protective by stimulating neurite outgrowth.

e) ApoE4 directly impairs the blood-brain-barrier function in AD.

In recent years, genome-wide association studies (GWASs) reinforce that AD is a complex disease, in which APP processing and immune response play key roles [212]. Whole genome sequencing (WGS), GWAS, and gene-expression network analysis proved that LOAD genetics implicates microglial pathways and CR1, SII1, MS4As, TREM2, ABCA7, CD33, INPP5D genes are associated with disease risk [212]. The results of the largest meta-GWAS approach (analyzing 19,089 AD cases) and follow-up analysis for AD risk has been published very recently [212]. It was found that altogether 39 genetic variants may be associated with AD risk (beyond the APOE variants). Polygenic risk scores (PRS) were used for identification of the following novel genetic variants: APP (new variants), SHARPIN, PRKD3/NDUFAF7, CHRNE, PLCG2 locus mutations.

The PRS approach could be a robust tool to predict the risk and the age of onset of AD. The latest studies on two AD mouse models demonstrate that microglia play a key role in AD pathogenesis, and $\mathrm{AD}$ risk genes converge to microglia [213]. If microglia were exposed to $A \beta$, novel genes have been significantly upregulated and expressed and, as a result, the microglia switched to an activated status. This unique gene expressing module included 11 novel genes (GPC2, TREML2, SYK, GRN, SLC2A5, SAMSN1, PYDC1, HEXB, RRBP1, LYN, and BLNK). It was hypothesized that the transition of $\mathrm{AD}$ from the prodromal, biochemical to clinical phase is determined by the combined inheritance of low-penetrant SNPs (Single Nucleotide Polymorphism), and multiple SNPs within the functional network push the homeostatic balance to disease-causing disturbances. The classical gene-based view of AD etiology should be changed.

\section{A $\beta$-Tau Crosstalk}

Several important questions are still to be answered in the $\mathrm{A} \beta$-tau relationship. It has not been fully understood how toxic actions of $\mathrm{A} \beta \mathrm{O}$ and TauO proceed. First, it was supposed that only $\mathrm{A} \beta$ triggers and regulates tau pathology in AD. However, there are many tauopathic diseases without any $\mathrm{A} \beta$ occurrence. Recent data show that cholesterol metabolism, endosomal trafficking, and ApoE and microglial activation can regulate tau pathology [214] in $A D$, independently from $A \beta$.

$A \beta$-tau crosstalk plays an important role in iron homeostasis of the brain [140]. The presence of soluble tau is necessary for promoting APP trafficking to the neuronal surface; this process lowers iron levels and prevents iron accumulation in the brain.

It is assumed that $\mathrm{A} \beta \mathrm{O}$ formation precedes the hyperphosphorylation of tau $[215,216]$, and $\mathrm{A} \beta$ pathology increases the production of tau [217]. It is also widely accepted that the two proteins have synergistic effects on AD progression. Many studies suggest that biological actions induce both pathologies via correlated, but independent pathways. A $\beta O$ may activate GSK3 $\beta$ that plays a key role in the hyperphosphorylation of tau. This modification changes the tau-tubulin binding, resulting in detachment of tau from the MT and TauO formation [218].

Several research groups studied tau-A $\beta$ cross-seeding $[219,220]$ and found that aggregated $A \beta$ promoted the formation of tau aggregates. It was demonstrated that $\mathrm{A} \beta \mathrm{O}$ enhances tau seeding in mouse neurons $[221,222]$ and facilitates intracellular tau aggregation by promoting the uptake of tau seeds. However, transduced $A \beta$ fibrils slightly reduce tau seeding.

It has been found very recently that tau and $A \beta$ cooperate in a mouse model, causing hyperactivity and transcriptional perturbations [223]. Both $A \beta$ and tau affects the activity of neuronal circuits. $A \beta$ 
promotes neuronal hyperactivity, while tau suppresses it [197]. Tau silenced most of the neurons and suppressed A $\beta$-dependent neuronal hyperactivity in an AD mouse model (APPxPS1 mice). Neuronal silencing dominated over $A \beta$-caused hyperactivity; however, only the soluble TauO had sufficient effect. The NFTs were inactive.

Current studies show that neuroinflammatory pathways also link together $\mathrm{A} \beta$ and tau effects. In microglia, if cells contact with $A \beta$, the inflammasomes become active and induce inflammation. However, NLRP3 inflammasome activation drives tau pathology by increasing tau accumulation within the neurons [224]. A visible link exists between $A \beta$ and tau: inflammatory processes promote A $\beta$-pathology and then also tau-pathology [198].

\section{Conclusions and Future Directions}

We do not have satisfactory knowledge on the mechanisms underlying the disease-this is the biggest problem in AD drug research. Two facts make Alzheimer's drug design an unbelievably complicated task: 1) Both $A \beta$ and tau proteins have pivotal physiological functions in the brain cells. 2) A small change in protein homeostasis (formation of ordered conformations, post-translational modifications) brings about formation of invisible toxic oligomers. Microscopically visible $A \beta$ and tau deposits are no genuine AD drug targets, and thus, the application of the original amyloid cascade hypothesis for drug design has limitations. In the last couple of years, a high number of AD drug development trials aiming to eliminate $A \beta$ plaques has failed [225-228]. (Only aducanumab, an $\mathrm{A} \beta \mathrm{O}$-specific antibody raised some optimism in clinical trials.) These failures may be originated from the fact that monomeric $A \beta$ plays important physiological functions, and some therapies might decrease $A \beta$ to a very low level. It is also possible that drug treatments begun too late, and the neurodegenerative processes were already irreversible. It has probably been a mistake to target amyloid plaques that now are considered to contain mainly non-toxic $A \beta$ fibrils and are also present in the brain of healthy individuals. It is possible that $A \beta$ accumulation is only a reaction of brain cells to their damage [24].

Drug research targeting tau assemblies received less attention. Nowadays, AD therapy is moving from $A \beta$ to tau. By now, novel physiological tau functions have been discovered that provide novel targets.

Biological aging bringing about protein dyshomeostasis is the most important risk factor of AD. One should understand why the aging brain is so vulnerable to AD pathogenesis. The results of biological gerontology provide targets for slowing down the aging process and prevent the early beginning of $\mathrm{AD}[229]$.

Novel developments in AD biomarkers and imaging methods provide excellent tools to follow and monitor the effectivity of new drug candidates in clinical trials. Tau-PET imaging with Flortaucipir may demonstrate and predict location of tau assemblies in AD patients [186]. New AD animal models represent better simulation of the human disease.

Nowadays, the following targets and directions seem to be the most important ones for novel AD drug developments:

Intracellular $A \beta$ oligomers ( $i A \beta O s$ ). Neutralizing antibodies, specific for $\mathrm{A} \beta \mathrm{O}$, ought to bind both extra- and (after entering the cells) iA $\beta O s$. Small peptidomimetic molecules that disaggregate oligomers to non-toxic monomers could also be used [230]. Maintaining the partly helical structure of $\mathrm{A} \beta$ monomers by helix stabilizing agents is under development.

Neutralizing intracellular TauOs might be the most promising target for AD drug research. Monoclonal ABs specific for TauO should be developed; however, these big molecules ought to enter the neurons. This process requires also the development of suitable vector molecules.

Dysfunctional resolution of chronic neuroinflammation is now considered as a driver of AD pathogenesis. Resolution of neuroinflammation by pro-homeostatic lipids (called specialized pro-resolving mediators, SPMs) might be a rational treatment in early stages of AD [231]. 
Restoration of protein homeostasis may be also rational drug targets. Tackling mitochondrial, metabolic, and vascular dysfunctions, modulating autophagy, preventing synaptic dysfunction, and increasing the clearance of amyloid proteins represent the therapies that slow down the aging process.

$\mathrm{A} \beta$ and tau interdependence is important in AD development and progress. In the future, a combination therapy, namely simultaneous administration of tau-targeting and A $\beta$-targeting drugs may be a useful remedy for AD treatment.

A rapid and successful development of cell-replacement therapies (e.g., application of multipotent stem cells) is expected for AD treatment [232].

Author Contributions: Conceptualization, B.P.; writing-original draft preparation, B.P., M.S. and F.B.; writing-review and editing, M.S. and F.B.; visualization F.B. All authors have read and agreed to the published version of the manuscript.

Funding: This work was supported by the grants GINOP-2.3.2-15- 2016-00060 and GINOP-2.3.2-15-2016-00034.

Conflicts of Interest: The authors declare no conflict of interest.

\section{Abbreviations}

$\mathrm{A} \beta$ oligomer $(\mathrm{A} \beta \mathrm{O})$, Alzheimer's disease $(\mathrm{AD})$, amyloid $\beta$ protein precursor protein $(\mathrm{APP})$, antibody $(\mathrm{AB})$, $\beta$-amyloid (A $\beta)$, electron microscopy $(\mathrm{EM})$, fibrillar $\beta$-amyloid (fA $\beta)$, glycogen synthase kinase $3(\mathrm{GSK}-3 \beta)$, intracellular $\beta$-amyloid (iA $\beta)$, intrinsically disordered protein (IDP), microtubule (MT), prion protein $(\operatorname{PrP})$, tau oligomer (TauO).

\section{References}

1. De Strooper, B.; Karran, E. The Cellular Phase of Alzheimer's Disease. Cell 2016, 164, 603-615. [CrossRef] [PubMed]

2. Francis, P.T.; Palmer, A.M.; Snape, M.; Wilcock, G.K. The cholinergic hypothesis of Alzheimer's disease: A review of progress. J. Neurol. Neurosurg. Psychiatry 1999, 66, 137-147. [CrossRef] [PubMed]

3. Hardy, J.; Allsop, D. Amyloid deposition as the central event in the aetiology of Alzheimer's disease. Trends Pharmacol. Sci. 1991, 12, 383-388. [CrossRef]

4. Lambert, M.P.; Barlow, A.K.; Chromy, B.A.; Edwards, C.; Freed, R.; Liosatos, M.; Morgan, T.E.; Rozovsky, I.; Trommer, B.; Viola, K.L.; et al. Diffusible, nonfibrillar ligands derived from A 1-42 are potent central nervous system neurotoxins. Proc. Natl. Acad. Sci. 1998, 95, 6448-6453. [CrossRef] [PubMed]

5. Grundke-Iqbal, I.; Iqbal, K.; Tung, Y.C.; Quinlan, M.; Wisniewski, H.M.; Binder, L.I. Abnormal phosphorylation of the microtubule-associated protein tau (tau) in Alzheimer cytoskeletal pathology. Proc. Natl. Acad. Sci. 1986, 83, 4913-4917. [CrossRef] [PubMed]

6. Small, S.A.; Duff, K. Linking A $\beta$ and Tau in Late-Onset Alzheimer's Disease: A Dual Pathway Hypothesis. Neuron 2008, 60, 534-542. [CrossRef]

7. Swerdlow, R.H.; Burns, J.M.; Khan, S.M. The Alzheimer's disease mitochondrial cascade hypothesis: Progress and perspectives. Biochim. Biophys. Acta BBA - Mol. Basis Dis. 2014, 1842, 1219-1231. [CrossRef]

8. Heppner, F.L.; Ransohoff, R.M.; Becher, B. Immune attack: The role of inflammation in Alzheimer disease. Nat. Rev. Neurosci. 2015, 16, 358-372. [CrossRef]

9. Di Marco, L.Y.; Venneri, A.; Farkas, E.; Evans, P.C.; Marzo, A.; Frangi, A.F. Vascular dysfunction in the pathogenesis of Alzheimer's disease - A review of endothelium-mediated mechanisms and ensuing vicious circles. Neurobiol. Dis. 2015, 82, 593-606. [CrossRef]

10. Bu, X.-L.; Xiang, Y.; Jin, W.-S.; Wang, J.; Shen, L.-L.; Huang, Z.-L.; Zhang, K.; Liu, Y.-H.; Zeng, F.; Liu, J.-H.; et al. Blood-derived amyloid- $\beta$ protein induces Alzheimer's disease pathologies. Mol. Psychiatry 2018, 23, 1948-1956. [CrossRef]

11. Kovacs, G. Molecular Pathological Classification of Neurodegenerative Diseases: Turning towards Precision Medicine. Int. J. Mol. Sci. 2016, 17, 189. [CrossRef] [PubMed]

12. Rahimi, J.; Kovacs, G.G. Prevalence of mixed pathologies in the aging brain. Alzheimers Res. Ther. 2014, 6, 82-93. [CrossRef] [PubMed]

13. Duyckaerts, C.; Delatour, B.; Potier, M.-C. Classification and basic pathology of Alzheimer disease. Acta Neuropathol. 2009, 118, 5-36. [CrossRef] [PubMed]

14. Castellani, R.J.; Rolston, R.K.; Smith, M.A. Alzheimer Disease. Dis. Mon. 2010, 56, 484-546. [CrossRef] 
15. Lane, C.A.; Hardy, J.; Schott, J.M. Alzheimer's disease. Eur. J. Neurol. 2018, 25, 59-70. [CrossRef]

16. Long, J.M.; Holtzman, D.M. Alzheimer Disease: An Update on Pathobiology and Treatment Strategies. Cell 2019, 179, 312-339. [CrossRef]

17. Choi, M.L.; Gandhi, S. Crucial role of protein oligomerization in the pathogenesis of Alzheimer's and Parkinson's diseases. FEBS J. 2018, 285, 3631-3644. [CrossRef]

18. Chiti, F.; Dobson, C.M. Protein Misfolding, Amyloid Formation, and Human Disease: A Summary of Progress Over the Last Decade. Annu. Rev. Biochem. 2017, 86, 27-68. [CrossRef]

19. Selkoe, D.J.; Hardy, J. The amyloid hypothesis of Alzheimer's disease at 25 years. EMBO Mol. Med. 2016, 8, 595-608. [CrossRef]

20. Cline, E.N.; Bicca, M.A.; Viola, K.L.; Klein, W.L. The Amyloid- $\beta$ Oligomer Hypothesis: Beginning of the Third Decade. J. Alzheimers Dis. 2018, 64, S567-S610. [CrossRef]

21. Chen, X.-Q.; Mobley, W.C. Alzheimer Disease Pathogenesis: Insights From Molecular and Cellular Biology Studies of Oligomeric A $\beta$ and Tau Species. Front. Neurosci. 2019, 13, 659-680. [CrossRef] [PubMed]

22. Rodgers, A.B. Progress Report on Alzheimer's Disease 2004-2005; U.S. Department of Health and Human Services, National Institutes on Aging, National Institutes of Health: Washington, DC, USA, 2005. Available online: http://www.agis.com/SqlFileResource.axd?id=441\&resource=pdf (accessed on 27 March 2020).

23. Castanho, I.; Murray, T.K.; Hannon, E.; Jeffries, A.; Walker, E.; Laing, E.; Baulf, H.; Harvey, J.; Bradshaw, L.; Randall, A.; et al. Transcriptional Signatures of Tau and Amyloid Neuropathology. Cell Rep. 2020, 30, $2040-2054$. [CrossRef] [PubMed]

24. Panza, F.; Lozupone, M.; Logroscino, G.; Imbimbo, B.P. A critical appraisal of amyloid- $\beta$-targeting therapies for Alzheimer disease. Nat. Rev. Neurol. 2019, 15, 73-88. [CrossRef] [PubMed]

25. Penke, B.; Bogár, F.; Paragi, G.; Gera, J.; Fülöp, L. Key Peptides and Proteins in Alzheimer's Disease. Curr. Protein Pept. Sci. 2019, 20, 577-599. [CrossRef] [PubMed]

26. Dawkins, E.; Small, D.H. Insights into the physiological function of the $\beta$-amyloid precursor protein: Beyond Alzheimer's disease. J. Neurochem. 2014, 129, 756-769. [CrossRef] [PubMed]

27. Nhan, H.S.; Chiang, K.; Koo, E.H. The multifaceted nature of amyloid precursor protein and its proteolytic fragments: Friends and foes. Acta Neuropathol. 2015, 129, 1-19. [CrossRef] [PubMed]

28. Caldwell, J.H.; Klevanski, M.; Saar, M.; Müller, U.C. Roles of the amyloid precursor protein family in the peripheral nervous system. Mech. Dev. 2013, 130, 433-446. [CrossRef]

29. Zhou, R.; Yang, G.; Guo, X.; Zhou, Q.; Lei, J.; Shi, Y. Recognition of the amyloid precursor protein by human $\gamma$-secretase. Science 2019, 363, eaaw0930. [CrossRef]

30. Tam, J.H.; Seah, C.; Pasternak, S.H. The Amyloid Precursor Protein is rapidly transported from the Golgi apparatus to the lysosome and where it is processed into beta-amyloid. Mol. Brain 2014, 7, 54-72. [CrossRef]

31. Deyts, C.; Thinakaran, G.; Parent, A.T. APP Receptor? To Be or Not To Be. Trends Pharmacol. Sci. 2016, 37, 390-411. [CrossRef]

32. Wildburger, N.C.; Esparza, T.J.; LeDuc, R.D.; Fellers, R.T.; Thomas, P.M.; Cairns, N.J.; Kelleher, N.L.; Bateman, R.J.; Brody, D.L. Diversity of Amyloid-beta Proteoforms in the Alzheimer's Disease Brain. Sci. Rep. 2017, 7, 9520-9529. [CrossRef] [PubMed]

33. Rudinskiy, N.; Fuerer, C.; Demurtas, D.; Zamorano, S.; De Piano, C.; Herrmann, A.G.; Spires-Jones, T.L.; Oeckl, P.; Otto, M.; Frosch, M.P.; et al. Amyloid-beta oligomerization is associated with the generation of a typical peptide fragment fingerprint. Alzheimers Dement. 2016, 12, 996-1013. [CrossRef] [PubMed]

34. Galante, D.; Ruggeri, F.S.; Dietler, G.; Pellistri, F.; Gatta, E.; Corsaro, A.; Florio, T.; Perico, A.; D'Arrigo, C. A critical concentration of N-terminal pyroglutamylated amyloid beta drives the misfolding of Ab1-42 into more toxic aggregates. Int. J. Biochem. Cell Biol. 2016, 79, 261-270. [CrossRef] [PubMed]

35. Tharp, W.G.; Sarkar, I. Origins of amyloid- $\beta$. BMC Genomics 2013, 14, 290-305. [CrossRef] [PubMed]

36. Brothers, H.M.; Gosztyla, M.L.; Robinson, S.R. The Physiological Roles of Amyloid- $\beta$ Peptide Hint at New Ways to Treat Alzheimer's Disease. Front. Aging Neurosci. 2018, 10, 118-134. [CrossRef]

37. Wang, S.; Bolós, M.; Clark, R.; Cullen, C.L.; Southam, K.A.; Foa, L.; Dickson, T.C.; Young, K.M. Amyloid $\beta$ precursor protein regulates neuron survival and maturation in the adult mouse brain. Mol. Cell. Neurosci. 2016, 77, 21-33. [CrossRef]

38. Hillen, H. The Beta Amyloid Dysfunction (BAD) Hypothesis for Alzheimer's Disease. Front. Neurosci. 2019, 13, 1154-1164. [CrossRef] 
39. Morley, J.E.; Farr, S.A. Hormesis and Amyloid- $\beta$ Protein: Physiology or Pathology? J. Alzheimers Dis. 2012, 29, 487-492. [CrossRef]

40. Lutter, L.; Serpell, C.J.; Tuite, M.F.; Xue, W.-F. The molecular lifecycle of amyloid - Mechanism of assembly, mesoscopic organisation, polymorphism, suprastructures, and biological consequences. Biochim. Biophys. BBA - Proteins Proteomics 2019, 1867, 140257-140271. [CrossRef]

41. Fändrich, M. Oligomeric Intermediates in Amyloid Formation: Structure Determination and Mechanisms of Toxicity. J. Mol. Biol. 2012, 421, 427-440. [CrossRef]

42. Ferreira, S.T.; Lourenco, M.V.; Oliveira, M.M.; De Felice, F.G. Soluble amyloid- $\beta$ oligomers as synaptotoxins leading to cognitive impairment in Alzheimer's disease. Front. Cell. Neurosci. 2015, 9. [CrossRef] [PubMed]

43. Hong, W.; Wang, Z.; Liu, W.; O’Malley, T.T.; Jin, M.; Willem, M.; Haass, C.; Frosch, M.P.; Walsh, D.M. Diffusible, highly bioactive oligomers represent a critical minority of soluble A $\beta$ in Alzheimer's disease brain. Acta Neuropathol. 2018, 136, 19-40. [CrossRef] [PubMed]

44. Georganopoulou, D.G.; Chang, L.; Nam, J.-M.; Thaxton, C.S.; Mufson, E.J.; Klein, W.L.; Mirkin, C.A. From The Cover: Nanoparticle-based detection in cerebral spinal fluid of a soluble pathogenic biomarker for Alzheimer's disease. Proc. Natl. Acad. Sci. 2005, 102, 2273-2276. [CrossRef] [PubMed]

45. Foroutanpay, B.V.; Kumar, J.; Kang, S.G.; Danaei, N.; Westaway, D.; Sim, V.L.; Kar, S. The Effects of N-terminal Mutations on $\beta$-amyloid Peptide Aggregation and Toxicity. Neuroscience 2018, 379, 177-188. [CrossRef]

46. Thu, T.T.M.; Co, N.T.; Tu, L.A.; Li, M.S. Aggregation rate of amyloid beta peptide is controlled by beta-content in monomeric state. J. Chem. Phys. 2019, 150, 225101-225109. [CrossRef]

47. Hamdan, N.; Kritsiligkou, P.; Grant, C.M. ER stress causes widespread protein aggregation and prion formation. J. Cell Biol. 2017, 216, 2295-2304. [CrossRef]

48. Barz, B.; Strodel, B. Understanding Amyloid- $\beta$ Oligomerization at the Molecular Level: The Role of the Fibril Surface. Chem. - Eur. J. 2016, 22, 8768-8772. [CrossRef]

49. Yan, T.; Liang, J.; Gao, J.; Wang, L.; Fujioka, H.; Zhu, X.; Wang, X. FAM222A encodes a protein which accumulates in plaques in Alzheimer's disease. Nat. Commun. 2020, 11, 411-427. [CrossRef]

50. Galzitskaya, O.V.; Galushko, E.I.; Selivanova, O.M. Studies of the Process of Amyloid Formation by A $\beta$ Peptide. Biochem. Mosc. 2018, 83, S62-S80. [CrossRef]

51. Bitan, G.; Kirkitadze, M.D.; Lomakin, A.; Vollers, S.S.; Benedek, G.B.; Teplow, D.B. Amyloid - protein (A) assembly: A 40 and A 42 oligomerize through distinct pathways. Proc. Natl. Acad. Sci. 2003, 100, 330-335. [CrossRef]

52. Törnquist, M.; Michaels, T.C.T.; Sanagavarapu, K.; Yang, X.; Meisl, G.; Cohen, S.I.A.; Knowles, T.P.J.; Linse, S. Secondary nucleation in amyloid formation. Chem. Commun. 2018, 54, 8667-8684. [CrossRef] [PubMed]

53. Owen, M.C.; Gnutt, D.; Gao, M.; Wärmländer, S.K.T.S.; Jarvet, J.; Gräslund, A.; Winter, R.; Ebbinghaus, S.; Strodel, B. Effects of in vivo conditions on amyloid aggregation. Chem. Soc. Rev. 2019, 48, 3946-3996. [CrossRef] [PubMed]

54. Roche, J.; Shen, Y.; Lee, J.H.; Ying, J.; Bax, A. Monomeric A $\beta^{1-40}$ and A $\beta^{1-42}$ Peptides in Solution Adopt Very Similar Ramachandran Map Distributions That Closely Resemble Random Coil. Biochemistry 2016, 55, 762-775. [CrossRef] [PubMed]

55. Wei, G.; Shea, J.-E. Effects of Solvent on the Structure of the Alzheimer Amyloid- $\beta(25-35)$ Peptide. Biophys. J. 2006, 91, 1638-1647. [CrossRef] [PubMed]

56. Zheng, W.; Tsai, M.-Y.; Wolynes, P.G. Comparing the Aggregation Free Energy Landscapes of Amyloid Beta(1-42) and Amyloid Beta(1-40). J. Am. Chem. Soc. 2017, 139, 16666-16676. [CrossRef]

57. Dovidchenko, N.V.; Glyakina, A.V.; Selivanova, O.M.; Grigorashvili, E.I.; Suvorina, M.Y.; Dzhus, U.F.; Mikhailina, A.O.; Shiliaev, N.G.; Marchenkov, V.V.; Surin, A.K.; et al. One of the possible mechanisms of amyloid fibrils formation based on the sizes of primary and secondary folding nuclei of $A \beta 40$ and $A \beta 42$. J. Struct. Biol. 2016, 194, 404-414. [CrossRef]

58. Ahmed, M.; Davis, J.; Aucoin, D.; Sato, T.; Ahuja, S.; Aimoto, S.; Elliott, J.I.; Van Nostrand, W.E.; Smith, S.O. Structural conversion of neurotoxic amyloid- $\beta 1-42$ oligomers to fibrils. Nat. Struct. Mol. Biol. 2010, 17, 561-567. [CrossRef]

59. Yu, L.; Edalji, R.; Harlan, J.E.; Holzman, T.F.; Lopez, A.P.; Labkovsky, B.; Hillen, H.; Barghorn, S.; Ebert, U.; Richardson, P.L.; et al. Structural Characterization of a Soluble Amyloid $\beta$-Peptide Oligomer. Biochemistry 2009, 48, 1870-1877. [CrossRef] 
60. Haupt, C.; Leppert, J.; Rönicke, R.; Meinhardt, J.; Yadav, J.K.; Ramachandran, R.; Ohlenschläger, O.; Reymann, K.G.; Görlach, M.; Fändrich, M. Structural Basis of $\beta$-Amyloid-Dependent Synaptic Dysfunctions. Angew. Chem. Int. Ed. 2012, 51, 1576-1579. [CrossRef]

61. Xiao, Y.; Matsuda, I.; Inoue, M.; Sasahara, T.; Hoshi, M.; Ishii, Y. NMR-based site-resolved profiling of $\beta$-amyloid misfolding reveals structural transitions from pathologically relevant spherical oligomer to fibril. J. Biol. Chem. 2020, 295, 458-467. [CrossRef]

62. Tycko, R. Amyloid Polymorphism: Structural Basis and Neurobiological Relevance. Neuron 2015, 86, 632-645. [CrossRef] [PubMed]

63. Meinhardt, J.; Sachse, C.; Hortschansky, P.; Grigorieff, N.; Fändrich, M. A $\beta(1-40)$ Fibril Polymorphism Implies Diverse Interaction Patterns in Amyloid Fibrils. J. Mol. Biol. 2009, 386, 869-877. [CrossRef] [PubMed]

64. Gray, E.G.; Paula-Barbosa, M.; Roher, A. Alzheimer's disease: Paired helical filaments and cytomembranes. Neuropathol. Appl. Neurobiol. 1987, 13, 91-110. [CrossRef] [PubMed]

65. Cohen, M.L.; Kim, C.; Haldiman, T.; ElHag, M.; Mehndiratta, P.; Pichet, T.; Lissemore, F.; Shea, M.; Cohen, Y.; Chen, W.; et al. Rapidly progressive Alzheimer's disease features distinct structures of amyloid- $\beta$. Brain 2015, 138, 1009-1022. [CrossRef] [PubMed]

66. Simone Ruggeri, F.; Habchi, J.; Cerreta, A.; Dietler, G. AFM-Based Single Molecule Techniques: Unraveling the Amyloid Pathogenic Species. Curr. Pharm. Des. 2016, 22, 3950-3970. [CrossRef] [PubMed]

67. Devitt, G.; Rice, W.; Crisford, A.; Nandhakumar, I.; Mudher, A.; Mahajan, S. Conformational Evolution of Molecular Signatures during Amyloidogenic Protein Aggregation. ACS Chem. Neurosci. 2019, 10, 4593-4611. [CrossRef]

68. Festa, G.; Mallamace, F.; Sancesario, G.M.; Corsaro, C.; Mallamace, D.; Fazio, E.; Arcidiacono, L.; Garcia Sakai, V.; Senesi, R.; Preziosi, E.; et al. Aggregation States of A $\beta 1-40, A \beta 1-42$ and A $\beta$ p3-42 Amyloid Beta Peptides: A SANS Study. Int. J. Mol. Sci. 2019, 20, 4126. [CrossRef]

69. Watanabe-Nakayama, T.; Ono, K.; Itami, M.; Takahashi, R.; Teplow, D.B.; Yamada, M. High-speed atomic force microscopy reveals structural dynamics of amyloid $\beta_{1-42}$ aggregates. Proc. Natl. Acad. Sci. 2016, 113, 5835-5840. [CrossRef]

70. Gremer, L.; Schölzel, D.; Schenk, C.; Reinartz, E.; Labahn, J.; Ravelli, R.B.G.; Tusche, M.; Lopez-Iglesias, C.; Hoyer, W.; Heise, H.; et al. Fibril structure of amyloid- $\beta(1-42)$ by cryo-electron microscopy. Science 2017, 358, 116-119. [CrossRef]

71. Buchete, N.-V.; Tycko, R.; Hummer, G. Molecular dynamics simulations of Alzheimer's beta-amyloid protofilaments. J. Mol. Biol. 2005, 353, 804-821. [CrossRef]

72. Urbanc, B.; Cruz, L.; Ding, F.; Sammond, D.; Khare, S.; Buldyrev, S.V.; Stanley, H.E.; Dokholyan, N.V. Molecular Dynamics Simulation of Amyloid $\beta$ Dimer Formation. Biophys. J. 2004, 87, 2310-2321. [CrossRef] [PubMed]

73. Sunde, M.; Blake, C. The Structure of Amyloid Fibrils by Electron Microscopy and X-Ray Diffraction. Adv. Protein Chem. 1997, 50, 123-159. [PubMed]

74. Colvin, M.T.; Silvers, R.; Ni, Q.Z.; Can, T.V.; Sergeyev, I.; Rosay, M.; Donovan, K.J.; Michael, B.; Wall, J.; Linse, S.; et al. Atomic Resolution Structure of Monomorphic A $\beta_{42}$ Amyloid Fibrils. J. Am. Chem. Soc. 2016, 138, 9663-9674. [CrossRef] [PubMed]

75. Lu, J.-X.; Qiang, W.; Yau, W.-M.; Schwieters, C.D.; Meredith, S.C.; Tycko, R. Molecular Structure of $\beta$-Amyloid Fibrils in Alzheimer's Disease Brain Tissue. Cell 2013, 154, 1257-1268. [CrossRef]

76. Wälti, M.A.; Ravotti, F.; Arai, H.; Glabe, C.G.; Wall, J.S.; Böckmann, A.; Güntert, P.; Meier, B.H.; Riek, R. Atomic-resolution structure of a disease-relevant $\mathrm{A} \beta(1-42)$ amyloid fibril. Proc. Natl. Acad. Sci. 2016, 113, E4976-E4984. [CrossRef]

77. Luhrs, T.; Ritter, C.; Adrian, M.; Riek-Loher, D.; Bohrmann, B.; Dobeli, H.; Schubert, D.; Riek, R. 3D structure of Alzheimer's amyloid- (1-42) fibrils. Proc. Natl. Acad. Sci. 2005, 102, 17342-17347. [CrossRef]

78. Kollmer, M.; Close, W.; Funk, L.; Rasmussen, J.; Bsoul, A.; Schierhorn, A.; Schmidt, M.; Sigurdson, C.J.; Jucker, M.; Fändrich, M. Cryo-EM structure and polymorphism of A $\beta$ amyloid fibrils purified from Alzheimer's brain tissue. Nat. Commun. 2019, 10, 4760-4768. [CrossRef]

79. Li, S.; Jin, M.; Koeglsperger, T.; Shepardson, N.E.; Shankar, G.M.; Selkoe, D.J. Soluble A $\beta$ oligomers inhibit long-term potentiation through a mechanism involving excessive activation of extrasynaptic NR2B-containing NMDA receptors. J. Neurosci. Off. J. Soc. Neurosci. 2011, 31, 6627-6638. [CrossRef] 
80. De Felice, F.G.; Wu, D.; Lambert, M.P.; Fernandez, S.J.; Velasco, P.T.; Lacor, P.N.; Bigio, E.H.; Jerecic, J.; Acton, P.J.; Shughrue, P.J.; et al. Alzheimer's disease-type neuronal tau hyperphosphorylation induced by A $\beta$ oligomers. Neurobiol. Aging 2008, 29, 1334-1347. [CrossRef]

81. De Felice, F.G.; Velasco, P.T.; Lambert, M.P.; Viola, K.; Fernandez, S.J.; Ferreira, S.T.; Klein, W.L. A $\beta$ Oligomers Induce Neuronal Oxidative Stress through an $N$-Methyl-D-aspartate Receptor-dependent Mechanism That Is Blocked by the Alzheimer Drug Memantine. J. Biol. Chem. 2007, 282, 11590-11601. [CrossRef]

82. Tabner, B.J.; El-Agnaf, O.M.A.; Turnbull, S.; German, M.J.; Paleologou, K.E.; Hayashi, Y.; Cooper, L.J.; Fullwood, N.J.; Allsop, D. Hydrogen Peroxide Is Generated during the Very Early Stages of Aggregation of the Amyloid Peptides Implicated in Alzheimer Disease and Familial British Dementia. J. Biol. Chem. 2005, 280, 35789-35792. [CrossRef] [PubMed]

83. Sponne, I.; Fifre, A.; Drouet, B.; Klein, C.; Koziel, V.; Pinçon-Raymond, M.; Olivier, J.-L.; Chambaz, J.; Pillot, T. Apoptotic Neuronal Cell Death Induced by the Non-fibrillar Amyloid- $\beta$ Peptide Proceeds through an Early Reactive Oxygen Species-dependent Cytoskeleton Perturbation. J. Biol. Chem. 2003, 278, 3437-3445. [CrossRef] [PubMed]

84. Longo, V.D.; Viola, K.L.; Klein, W.L.; Finch, C.E. Reversible Inactivation of Superoxide-Sensitive Aconitase in A 31-42-Treated Neuronal Cell Lines. J. Neurochem. 2002, 75, 1977-1985. [CrossRef] [PubMed]

85. Tomiyama, T.; Matsuyama, S.; Iso, H.; Umeda, T.; Takuma, H.; Ohnishi, K.; Ishibashi, K.; Teraoka, R.; Sakama, N.; Yamashita, T.; et al. A Mouse Model of Amyloid Oligomers: Their Contribution to Synaptic Alteration, Abnormal Tau Phosphorylation, Glial Activation, and Neuronal Loss In Vivo. J. Neurosci. 2010, 30, 4845-4856. [CrossRef] [PubMed]

86. Maezawa, I.; Zimin, P.I.; Wulff, H.; Jin, L.-W. Amyloid- $\beta$ Protein Oligomer at Low Nanomolar Concentrations Activates Microglia and Induces Microglial Neurotoxicity. J. Biol. Chem. 2011, 286, 3693-3706. [CrossRef] [PubMed]

87. Hu, J.; Akama, K.T.; Krafft, G.A.; Chromy, B.A.; Van Eldik, L.J. Amyloid- $\beta$ peptide activates cultured astrocytes: Morphological alterations, cytokine induction and nitric oxide release. Brain Res. 1998, 785, 195-206. [CrossRef]

88. Ferretti, M.T.; Bruno, M.A.; Ducatenzeiler, A.; Klein, W.L.; Cuello, A.C. Intracellular A $\beta$-oligomers and early inflammation in a model of Alzheimer's disease. Neurobiol. Aging 2012, 33, 1329-1342. [CrossRef]

89. Nishitsuji, K.; Tomiyama, T.; Ishibashi, K.; Ito, K.; Teraoka, R.; Lambert, M.P.; Klein, W.L.; Mori, H. The E693 Mutation in Amyloid Precursor Protein Increases Intracellular Accumulation of Amyloid $\beta$ Oligomers and Causes Endoplasmic Reticulum Stress-Induced Apoptosis in Cultured Cells. Am. J. Pathol. 2009, 174, 957-969. [CrossRef]

90. Umeda, T.; Tomiyama, T.; Sakama, N.; Tanaka, S.; Lambert, M.P.; Klein, W.L.; Mori, H. Intraneuronal amyloid $\beta$ oligomers cause cell death via endoplasmic reticulum stress, endosomal/lysosomal leakage, and mitochondrial dysfunction in vivo. J. Neurosci. Res. 2011, 89, 1031-1042. [CrossRef]

91. Resende, R.; Ferreiro, E.; Pereira, C.; Oliveira, C.R. ER stress is involved in A $\beta$-induced GSK-3 $\beta$ activation and tau phosphorylation. J. Neurosci. Res. 2008, 86, 2091-2099. [CrossRef]

92. Shankar, G.M.; Bloodgood, B.L.; Townsend, M.; Walsh, D.M.; Selkoe, D.J.; Sabatini, B.L. Natural Oligomers of the Alzheimer Amyloid- Protein Induce Reversible Synapse Loss by Modulating an NMDA-Type Glutamate Receptor-Dependent Signaling Pathway. J. Neurosci. 2007, 27, 2866-2875. [CrossRef] [PubMed]

93. Lacor, P.N.; Buniel, M.C.; Furlow, P.W.; Sanz Clemente, A.; Velasco, P.T.; Wood, M.; Viola, K.L.; Klein, W.L. A Oligomer-Induced Aberrations in Synapse Composition, Shape, and Density Provide a Molecular Basis for Loss of Connectivity in Alzheimer's Disease. J. Neurosci. 2007, 27, 796-807. [CrossRef] [PubMed]

94. Pickett, E.K.; Koffie, R.M.; Wegmann, S.; Henstridge, C.M.; Herrmann, A.G.; Colom-Cadena, M.; Lleo, A.; Kay, K.R.; Vaught, M.; Soberman, R.; et al. Non-Fibrillar Oligomeric Amyloid- $\beta$ within Synapses. J. Alzheimers Dis. 2016, 53, 787-800. [CrossRef] [PubMed]

95. Tomiyama, T.; Nagata, T.; Shimada, H.; Teraoka, R.; Fukushima, A.; Kanemitsu, H.; Takuma, H.; Kuwano, R.; Imagawa, M.; Ataka, S.; et al. A new amyloid $\beta$ variant favoring oligomerization in Alzheimer's-type dementia. Ann. Neurol. 2008, 63, 377-387. [CrossRef]

96. Shimada, H.; Ataka, S.; Tomiyama, T.; Takechi, H.; Mori, H.; Miki, T. Clinical Course of Patients with Familial Early-Onset Alzheimer's Disease Potentially Lacking Senile Plaques Bearing the E693 $\Delta$ Mutation in Amyloid Precursor Protein. Dement. Geriatr. Cogn. Disord. 2011, 32, 45-54. [CrossRef]

97. Inayathullah, M.; Teplow, D.B. Structural dynamics of the $\Delta \mathrm{E} 22$ (Osaka) familial Alzheimer's disease-linked amyloid $\beta$-protein. Amyloid 2011, 18, 98-107. [CrossRef] 
98. Lambert, M.P.; Velasco, P.T.; Chang, L.; Viola, K.L.; Fernandez, S.; Lacor, P.N.; Khuon, D.; Gong, Y.; Bigio, E.H.; Shaw, P.; et al. Monoclonal antibodies that target pathological assemblies of A $\beta$. J. Neurochem. 2007, 100, $23-35$. [CrossRef]

99. Zameer, A.; Kasturirangan, S.; Emadi, S.; Nimmagadda, S.V.; Sierks, M.R. Anti-oligomeric A $\beta$ Single-chain Variable Domain Antibody Blocks A $\beta$-induced Toxicity Against Human Neuroblastoma Cells. J. Mol. Biol. 2008, 384, 917-928. [CrossRef]

100. Klyubin, I.; Walsh, D.M.; Lemere, C.A.; Cullen, W.K.; Shankar, G.M.; Betts, V.; Spooner, E.T.; Jiang, L.; Anwyl, R.; Selkoe, D.J.; et al. Amyloid $\beta$ protein immunotherapy neutralizes A $\beta$ oligomers that disrupt synaptic plasticity in vivo. Nat. Med. 2005, 11, 556-561. [CrossRef]

101. Xiao, C.; Davis, F.J.; Chauhan, B.C.; Viola, K.L.; Lacor, P.N.; Velasco, P.T.; Klein, W.L.; Chauhan, N.B. Brain Transit and Ameliorative Effects of Intranasally Delivered Anti-Amyloid- $\beta$ Oligomer Antibody in 5XFAD Mice. J. Alzheimers Dis. 2013, 35, 777-788. [CrossRef]

102. Zhao, M.; Wang, S.; Wang, Y.; Zhang, R.; Li, Y.; Su, Y.; Zhou, W.; Yu, X.; Liu, R. Pan-Amyloid Oligomer Specific scFv Antibody Attenuates Memory Deficits and Brain Amyloid Burden in Mice with Alzheimer's Disease. Curr. Alzheimer Res. 2014, 11, 69-78. [CrossRef]

103. Sebollela, A.; Cline, E.N.; Popova, I.; Luo, K.; Sun, X.; Ahn, J.; Barcelos, M.A.; Bezerra, V.N.; Lyra e Silva, N.M.; Patel, J.; et al. A human $\mathrm{scFv}$ antibody that targets and neutralizes high molecular weight pathogenic amyloid- $\beta$ oligomers. J. Neurochem. 2017, 142, 934-947. [CrossRef] [PubMed]

104. Arispe, N. Architecture of the Alzheimer's A beta P Ion Channel Pore. J. Membr. Biol. 2004, 197, 33-48. [CrossRef] [PubMed]

105. Evangelisti, E.; Wright, D.; Zampagni, M.; Cascella, R.; Fiorillo, C.; Bagnoli, S.; Relini, A.; Nichino, D.; Scartabelli, T.; Nacmias, B.; et al. Lipid Rafts Mediate Amyloid-Induced Calcium Dyshomeostasis and Oxidative Stress in Alzheimer's Disease. Curr. Alzheimer Res. 2013, 10, 143-153. [CrossRef] [PubMed]

106. Lacor, P.N. Synaptic Targeting by Alzheimer's-Related Amyloid Oligomers. J. Neurosci. 2004, 24, 10191-10200. [CrossRef] [PubMed]

107. Gong, Y.; Chang, L.; Viola, K.L.; Lacor, P.N.; Lambert, M.P.; Finch, C.E.; Krafft, G.A.; Klein, W.L. Alzheimer's disease-affected brain: Presence of oligomeric A ligands (ADDLs) suggests a molecular basis for reversible memory loss. Proc. Natl. Acad. Sci. 2003, 100, 10417-10422. [CrossRef] [PubMed]

108. Zhao, W.-Q.; De Felice, F.G.; Fernandez, S.; Chen, H.; Lambert, M.P.; Quon, M.J.; Krafft, G.A.; Klein, W.L. Amyloid beta oligomers induce impairment of neuronal insulin receptors. FASEB J. 2008, 22, 246-260. [CrossRef]

109. Renner, M.; Lacor, P.N.; Velasco, P.T.; Xu, J.; Contractor, A.; Klein, W.L.; Triller, A. Deleterious Effects of Amyloid $\beta$ Oligomers Acting as an Extracellular Scaffold for mGluR5. Neuron 2010, 66, 739-754. [CrossRef]

110. Thathiah, A.; De Strooper, B. The role of $G$ protein-coupled receptors in the pathology of Alzheimer's disease. Nat. Rev. Neurosci. 2011, 12, 73-87. [CrossRef]

111. Godoy, J.A.; Rios, J.A.; Zolezzi, J.M.; Braidy, N.; Inestrosa, N.C. Signaling pathway cross talk in Alzheimer's disease. Cell Commun. Signal. 2014, 12, 23-35. [CrossRef]

112. Magdesian, M.H.; Carvalho, M.M.V.F.; Mendes, F.A.; Saraiva, L.M.; Juliano, M.A.; Juliano, L.; Garcia-Abreu, J.; Ferreira, S.T. Amyloid- $\beta$ Binds to the Extracellular Cysteine-rich Domain of Frizzled and Inhibits Wnt/ $\beta$-Catenin Signaling. J. Biol. Chem. 2008, 283, 9359-9368. [CrossRef] [PubMed]

113. Ding, Y.; Zhao, J.; Zhang, X.; Wang, S.; Viola, K.L.; Chow, F.E.; Zhang, Y.; Lippa, C.; Klein, W.L.; Gong, Y. Amyloid Beta Oligomers Target to Extracellular and Intracellular Neuronal Synaptic Proteins in Alzheimer's Disease. Front. Neurol. 2019, 10, 1140-1156. [CrossRef] [PubMed]

114. Smith, L.M.; Kostylev, M.A.; Lee, S.; Strittmatter, S.M. Systematic and standardized comparison of reported amyloid- $\beta$ receptors for sufficiency, affinity, and Alzheimer's disease relevance. J. Biol. Chem. 2019, 294, 6042-6053. [CrossRef] [PubMed]

115. Nygaard, H.B.; van Dyck, C.H.; Strittmatter, S.M. Fyn kinase inhibition as a novel therapy for Alzheimer's disease. Alzheimers Res. Ther. 2014, 6, 8-16. [CrossRef] [PubMed]

116. Zhang, Y.; Zhao, Y.; Zhang, L.; Yu, W.; Wang, Y.; Chang, W. Cellular Prion Protein as a Receptor of Toxic Amyloid- $\beta 42$ Oligomers Is Important for Alzheimer's Disease. Front. Cell. Neurosci. 2019, 13, 339-348. [CrossRef] [PubMed] 
117. Salazar, S.V.; Gallardo, C.; Kaufman, A.C.; Herber, C.S.; Haas, L.T.; Robinson, S.; Manson, J.C.; Lee, M.K.; Strittmatter, S.M. Conditional Deletion of Prnp Rescues Behavioral and Synaptic Deficits after Disease Onset in Transgenic Alzheimer's Disease. J. Neurosci. 2017, 37, 9207-9221. [CrossRef] [PubMed]

118. Ohnishi, T.; Yanazawa, M.; Sasahara, T.; Kitamura, Y.; Hiroaki, H.; Fukazawa, Y.; Kii, I.; Nishiyama, T.; Kakita, A.; Takeda, H.; et al. Na, K-ATPase $\alpha 3$ is a death target of Alzheimer patient amyloid- $\beta$ assembly. Proc. Natl. Acad. Sci. 2015, 112, E4465-E4474. [CrossRef]

119. DiChiara, T.; DiNunno, N.; Clark, J.; Bu, R.L.; Cline, E.N.; Rollins, M.G.; Gong, Y.; Brody, D.L.; Sligar, S.G.; Velasco, P.T.; et al. Alzheimer's Toxic Amyloid Beta Oligomers: Unwelcome Visitors to the Na/K ATPase alpha3 Docking Station. Yale J. Biol. Med. 2017, 90, 45-61.

120. Zhang, F.; Gannon, M.; Chen, Y.; Yan, S.; Zhang, S.; Feng, W.; Tao, J.; Sha, B.; Liu, Z.; Saito, T.; et al. $\beta$-amyloid redirects norepinephrine signaling to activate the pathogenic GSK3 $\beta /$ tau cascade. Sci. Transl. Med. 2020, 12, eaay6931. [CrossRef]

121. Findley, C.A.; Bartke, A.; Hascup, K.N.; Hascup, E.R. Amyloid Beta-Related Alterations to Glutamate Signaling Dynamics During Alzheimer's Disease Progression. ASN Neuro 2019, 11. [CrossRef]

122. Goulay, R.; Mena Romo, L.; Hol, E.M.; Dijkhuizen, R.M. From Stroke to Dementia: A Comprehensive Review Exposing Tight Interactions Between Stroke and Amyloid- $\beta$ Formation. Transl. Stroke Res. 2019. [CrossRef] [PubMed]

123. Zhao, Y.; Wu, X.; Li, X.; Jiang, L.-L.; Gui, X.; Liu, Y.; Sun, Y.; Zhu, B.; Piña-Crespo, J.C.; Zhang, M.; et al. TREM2 Is a Receptor for $\beta$-Amyloid that Mediates Microglial Function. Neuron 2018, 97, 1023-1031. [CrossRef] [PubMed]

124. Patel, P.; Shah, J. Role of Vitamin D in Amyloid clearance via LRP-1 upregulation in Alzheimer's disease: A potential therapeutic target? J. Chem. Neuroanat. 2017, 85, 36-42. [CrossRef] [PubMed]

125. Bückig, A.; Tikkanen, R.; Herzog, V.; Schmitz, A. Cytosolic and nuclear aggregation of the amyloid $\beta$-peptide following its expression in the endoplasmic reticulum. Histochem. Cell Biol. 2002, 118, 353-360. [CrossRef] [PubMed]

126. Gouras, G.K.; Tsai, J.; Naslund, J.; Vincent, B.; Edgar, M.; Checler, F.; Greenfield, J.P.; Haroutunian, V.; Buxbaum, J.D.; Xu, H.; et al. Intraneuronal A $\beta 42$ Accumulation in Human Brain. Am. J. Pathol. 2000, 156, 15-20. [CrossRef]

127. Bayer, T.A.; Wirths, O. Intracellular accumulation of amyloid-beta - a predictor for synaptic dysfunction and neuron loss in Alzheimer's disease. Front. Aging Neurosci. 2010, 2, 8-18. [CrossRef]

128. Takahashi, R.H.; Nagao, T.; Gouras, G.K. Plaque formation and the intraneuronal accumulation of $\beta$-amyloid in Alzheimer's disease: Intraneuronal accumulation of $\beta$-amyloid. Pathol. Int. 2017, 67, 185-193. [CrossRef]

129. Brewer, G.J.; Herrera, R.A.; Philipp, S.; Sosna, J.; Reyes-Ruiz, J.M.; Glabe, C.G. Age-Related Intraneuronal Aggregation of Amyloid- $\beta$ in Endosomes, Mitochondria, Autophagosomes, and Lysosomes. J. Alzheimers Dis. 2020, 73, 229-246. [CrossRef]

130. Hartmann, T.; Bieger, S.C.; Brühl, B.; Tienari, P.J.; Ida, N.; Allsop, D.; Roberts, G.W.; Masters, C.L.; Dotti, C.G.; Unsicker, K.; et al. Distinct sites of intracellular production for Alzheimer's disease A $\beta 40 / 42$ amyloid peptides. Nat. Med. 1997, 3, 1016-1020. [CrossRef]

131. Pacheco-Quinto, J.; Eckman, E.A. Endothelin-converting Enzymes Degrade Intracellular $\beta$-Amyloid Produced within the Endosomal/Lysosomal Pathway and Autophagosomes. J. Biol. Chem. 2013, 288, 5606-5615. [CrossRef]

132. Lacosta, A.-M.; Insua, D.; Badi, H.; Pesini, P.; Sarasa, M. Neurofibrillary Tangles of A $\beta x-40$ in Alzheimer's Disease Brains. J. Alzheimers Dis. 2017, 58, 661-667. [CrossRef] [PubMed]

133. Zhao, X.-L.; Wang, W.-A.; Tan, J.-X.; Huang, J.-K.; Zhang, X.; Zhang, B.-Z.; Wang, Y.-H.; YangCheng, H.-Y.; Zhu, H.-L.; Sun, X.-J.; et al. Expression of -Amyloid Induced Age-Dependent Presynaptic and Axonal Changes in Drosophila. J. Neurosci. 2010, 30, 1512-1522. [CrossRef] [PubMed]

134. Olsson, T.T.; Klementieva, O.; Gouras, G.K. Prion-like seeding and nucleation of intracellular amyloid- $\beta$. Neurobiol. Dis. 2018, 113, 1-10. [CrossRef] [PubMed]

135. Meyer-Luehmann, M.; Spires-Jones, T.L.; Prada, C.; Garcia-Alloza, M.; de Calignon, A.; Rozkalne, A.; Koenigsknecht-Talboo, J.; Holtzman, D.M.; Bacskai, B.J.; Hyman, B.T. Rapid appearance and local toxicity of amyloid- $\beta$ plaques in a mouse model of Alzheimer's disease. Nature 2008, 451, 720-724. [CrossRef] [PubMed] 
136. Querol-Vilaseca, M.; Colom-Cadena, M.; Pegueroles, J.; Nuñez-Llaves, R.; Luque-Cabecerans, J.; Muñoz-Llahuna, L.; Andilla, J.; Belbin, O.; Spires-Jones, T.L.; Gelpi, E.; et al. Nanoscale structure of amyloid- $\beta$ plaques in Alzheimer's disease. Sci. Rep. 2019, 9, 5181-5191. [CrossRef]

137. Masters, C.L.; Multhaup, G.; Simms, G.; Pottgiesser, J.; Martins, R.N.; Beyreuther, K. Neuronal origin of a cerebral amyloid: Neurofibrillary tangles of Alzheimer's disease contain the same protein as the amyloid of plaque cores and blood vessels. EMBO J. 1985, 4, 2757-2763. [CrossRef]

138. Gkanatsiou, E.; Portelius, E.; Toomey, C.E.; Blennow, K.; Zetterberg, H.; Lashley, T.; Brinkmalm, G. A distinct brain beta amyloid signature in cerebral amyloid angiopathy compared to Alzheimer's disease. Neurosci. Lett. 2019, 701, 125-131. [CrossRef]

139. Tapia-Rojas, C.; Cabezas-Opazo, F.; Deaton, C.A.; Vergara, E.H.; Johnson, G.V.W.; Quintanilla, R.A. It's all about tau. Prog. Neurobiol. 2019, 175, 54-76. [CrossRef]

140. Chong, F.P.; Ng, K.Y.; Koh, R.Y.; Chye, S.M. Tau Proteins and Tauopathies in Alzheimer's Disease. Cell. Mol. Neurobiol. 2018, 38, 965-980. [CrossRef]

141. Mroczko; Groblewska; Litman-Zawadzka The Role of Protein Misfolding and Tau Oligomers (TauOs) in Alzheimer's Disease (AD). Int. J. Mol. Sci. 2019, 20, 4661. [CrossRef]

142. Almansoub, H.A.M.M.; Tang, H.; Wu, Y.; Wang, D.-Q.; Mahaman, Y.A.R.; Wei, N.; Almansob, Y.A.M.; He, W.; Liu, D. Tau Abnormalities and the Potential Therapy in Alzheimer's Disease. J. Alzheimers Dis. 2019, 67, $13-33$. [CrossRef] [PubMed]

143. Arakhamia, T.; Lee, C.E.; Carlomagno, Y.; Duong, D.M.; Kundinger, S.R.; Wang, K.; Williams, D.; DeTure, M.; Dickson, D.W.; Cook, C.N.; et al. Posttranslational Modifications Mediate the Structural Diversity of Tauopathy Strains. Cell 2020, 180, 633-644. [CrossRef] [PubMed]

144. Sergeant, N.; Bretteville, A.; Hamdane, M.; Caillet-Boudin, M.-L.; Grognet, P.; Bombois, S.; Blum, D.; Delacourte, A.; Pasquier, F.; Vanmechelen, E.; et al. Biochemistry of Tau in Alzheimer's disease and related neurological disorders. Expert Rev. Proteomics 2008, 5, 207-224. [CrossRef] [PubMed]

145. Sengupta, A.; Kabat, J.; Novak, M.; Wu, Q.; Grundke-Iqbal, I.; Iqbal, K. Phosphorylation of Tau at Both Thr 231 and Ser 262 Is Required for Maximal Inhibition of Its Binding to Microtubules. Arch. Biochem. Biophys. 1998, 357, 299-309. [CrossRef] [PubMed]

146. Dickey, C.A.; Kamal, A.; Lundgren, K.; Klosak, N.; Bailey, R.M.; Dunmore, J.; Ash, P.; Shoraka, S.; Zlatkovic, J.; Eckman, C.B.; et al. The high-affinity HSP90-CHIP complex recognizes and selectively degrades phosphorylated tau client proteins. J. Clin. Invest. 2007, 117, 648-658. [CrossRef]

147. Barthélemy, N.R.; Li, Y.; Joseph-Mathurin, N.; Gordon, B.A.; Hassenstab, J.; Benzinger, T.L.S.; Buckles, V.; Fagan, A.M.; Perrin, R.J.; Goate, A.M.; et al. A soluble phosphorylated tau signature links tau, amyloid and the evolution of stages of dominantly inherited Alzheimer's disease. Nat. Med. 2020, 26, 398-407. [CrossRef]

148. Dawson, H.N.; Ferreira, A.; Eyster, M.V.; Ghoshal, N.; Binder, L.I.; Vitek, M.P. Inhibition of neuronal maturation in primary hippocampal neurons from tau deficient mice. J. Cell Sci. 2001, 114, 1179-1187.

149. Lei, P.; Ayton, S.; Finkelstein, D.I.; Spoerri, L.; Ciccotosto, G.D.; Wright, D.K.; Wong, B.X.W.; Adlard, P.A.; Cherny, R.A.; Lam, L.Q.; et al. Tau deficiency induces parkinsonism with dementia by impairing APP-mediated iron export. Nat. Med. 2012, 18, 291-295. [CrossRef]

150. Ma, Q.-L.; Zuo, X.; Yang, F.; Ubeda, O.J.; Gant, D.J.; Alaverdyan, M.; Kiosea, N.C.; Nazari, S.; Chen, P.P.; Nothias, F.; et al. Loss of MAP Function Leads to Hippocampal Synapse Loss and Deficits in the Morris Water Maze with Aging. J. Neurosci. 2014, 34, 7124-7136. [CrossRef]

151. Bi, M.; Gladbach, A.; van Eersel, J.; Ittner, A.; Przybyla, M.; van Hummel, A.; Chua, S.W.; van der Hoven, J.; Lee, W.S.; Müller, J.; et al. Tau exacerbates excitotoxic brain damage in an animal model of stroke. Nat. Commun. 2017, 8, 473-488. [CrossRef]

152. Tuo, Q.; Lei, P.; Jackman, K.A.; Li, X.; Xiong, H.; Li, X.; Liuyang, Z.; Roisman, L.; Zhang, S.; Ayton, S.; et al. Tau-mediated iron export prevents ferroptotic damage after ischemic stroke. Mol. Psychiatry 2017, 22, 1520-1530. [CrossRef] [PubMed]

153. Naseri, N.N.; Wang, H.; Guo, J.; Sharma, M.; Luo, W. The complexity of tau in Alzheimer's disease. Neurosci. Lett. 2019, 705, 183-194. [CrossRef] [PubMed]

154. Sultan, A.; Nesslany, F.; Violet, M.; Bégard, S.; Loyens, A.; Talahari, S.; Mansuroglu, Z.; Marzin, D.; Sergeant, N.; Humez, S.; et al. Nuclear Tau, a Key Player in Neuronal DNA Protection. J. Biol. Chem. 2011, 286, 4566-4575. [CrossRef] 
155. Lee, G.; Newman, S.T.; Gard, D.L.; Band, H.; Panchamoorthy, G. Tau interacts with src-family non-receptor tyrosine kinases. J. Cell Sci. 1998, 111, 3167-3177.

156. Ittner, L.M.; Ke, Y.D.; Delerue, F.; Bi, M.; Gladbach, A.; van Eersel, J.; Wölfing, H.; Chieng, B.C.; Christie, M.J.; Napier, I.A.; et al. Dendritic Function of Tau Mediates Amyloid- $\beta$ Toxicity in Alzheimer's Disease Mouse Models. Cell 2010, 142, 387-397. [CrossRef] [PubMed]

157. Pooler, A.M.; Noble, W.; Hanger, D.P. A role for tau at the synapse in Alzheimer's disease pathogenesis. Neuropharmacology 2014, 76, 1-8. [CrossRef]

158. Gong, C.-X.; Liu, F.; Grundke-Iqbal, I.; Iqbal, K. Post-translational modifications of tau protein in Alzheimer's disease. J. Neural Transm. 2005, 112, 813-838. [CrossRef]

159. Marcus, J.N.; Schachter, J. Targeting Post-translational Modifications on Tau as a Therapeutic Strategy for Alzheimer's Disease. J. Neurogenet. 2011, 25, 127-133. [CrossRef]

160. Hervy, J.; Bicout, D.J. Dynamical decoration of stabilized-microtubules by Tau-proteins. Sci. Rep. 2019, 9, 12473-12488. [CrossRef]

161. Yeboah, F.; Kim, T.-E.; Bill, A.; Dettmer, U. Dynamic behaviors of $\alpha$-synuclein and tau in the cellular context: New mechanistic insights and therapeutic opportunities in neurodegeneration. Neurobiol. Dis. 2019, 132, 104543-104558. [CrossRef]

162. Kolarova, M.; García-Sierra, F.; Bartos, A.; Ricny, J.; Ripova, D. Structure and Pathology of Tau Protein in Alzheimer Disease. Int. J. Alzheimers Dis. 2012, 2012, 1-13. [CrossRef] [PubMed]

163. Mandelkow, E.-M.; Biernat, J.; Drewes, G.; Gustke, N.; Trinczek, B.; Mandelkow, E. Tau domains, phosphorylation, and interactions with microtubules. Neurobiol. Aging 1995, 16, 355-362. [CrossRef]

164. Brady, S.T.; Sperry, A.O. Biochemical and functional diversity of microtubule motors in the nervous system. Curr. Opin. Neurobiol. 1995, 5, 551-558. [CrossRef]

165. Baas, P.W.; Qiang, L. Tau: It's Not What You Think. Trends Cell Biol. 2019, 29, 452-461. [CrossRef]

166. Mandelkow, E.-M.; Mandelkow, E. Biochemistry and Cell Biology of Tau Protein in Neurofibrillary Degeneration. Cold Spring Harb. Perspect. Med. 2012, 2, a006247-a006273. [CrossRef]

167. Kellogg, E.H.; Hejab, N.M.A.; Poepsel, S.; Downing, K.H.; DiMaio, F.; Nogales, E. Near-atomic model of microtubule-tau interactions. Science 2018, 360, 1242-1246. [CrossRef]

168. Dixit, R.; Ross, J.L.; Goldman, Y.E.; Holzbaur, E.L.F. Differential Regulation of Dynein and Kinesin Motor Proteins by Tau. Science 2008, 319, 1086-1089. [CrossRef]

169. Reddy, P.H. Abnormal tau, mitochondrial dysfunction, impaired axonal transport of mitochondria, and synaptic deprivation in Alzheimer's disease. Brain Res. 2011, 1415, 136-148. [CrossRef]

170. He, J.; Zhou, R.; Wu, Z.; Carrasco, M.A.; Kurshan, P.T.; Farley, J.E.; Simon, D.J.; Wang, G.; Han, B.; Hao, J.; et al. Prevalent presence of periodic actin-spectrin-based membrane skeleton in a broad range of neuronal cell types and animal species. Proc. Natl. Acad. Sci. 2016, 113, 6029-6034. [CrossRef]

171. Zhang, R.; Zhang, C.; Zhao, Q.; Li, D. Spectrin: Structure, function and disease. Sci. China Life Sci. 2013, 56, 1076-1085. [CrossRef]

172. Morris, M.; Maeda, S.; Vossel, K.; Mucke, L. The Many Faces of Tau. Neuron 2011, 70, 410-426. [CrossRef]

173. Marciniak, E.; Leboucher, A.; Caron, E.; Ahmed, T.; Tailleux, A.; Dumont, J.; Issad, T.; Gerhardt, E.; Pagesy, P.; Vileno, M.; et al. Tau deletion promotes brain insulin resistance. J. Exp. Med. 2017, 214, 2257-2269. [CrossRef] [PubMed]

174. Shafiei, S.S.; Guerrero-Muñoz, M.J.; Castillo-Carranza, D.L. Tau Oligomers: Cytotoxicity, Propagation, and Mitochondrial Damage. Front. Aging Neurosci. 2017, 9, 83-92. [CrossRef] [PubMed]

175. Frandemiche, M.L.; De Seranno, S.; Rush, T.; Borel, E.; Elie, A.; Arnal, I.; Lante, F.; Buisson, A. Activity-Dependent Tau Protein Translocation to Excitatory Synapse Is Disrupted by Exposure to Amyloid-Beta Oligomers. J. Neurosci. 2014, 34, 6084-6097. [CrossRef] [PubMed]

176. Friedhoff, P.; von Bergen, M.; Mandelkow, E.-M.; Mandelkow, E. Structure of tau protein and assembly into paired helical filaments. Biochim. Biophys. BBA-Mol. Basis Dis. 2000, 1502, 122-132. [CrossRef]

177. Mukrasch, M.D.; Bibow, S.; Korukottu, J.; Jeganathan, S.; Biernat, J.; Griesinger, C.; Mandelkow, E.; Zweckstetter, M. Structural Polymorphism of 441-Residue Tau at Single Residue Resolution. PLoS Biol. 2009, 7, e1000034. [CrossRef] [PubMed]

178. Takeda, S. Progression of Alzheimer's disease, tau propagation, and its modifiable risk factors. Neurosci. Res. 2019, 141, 36-42. [CrossRef] 
179. Fanni, A.M.; Vander Zanden, C.M.; Majewska, P.V.; Majewski, J.; Chi, E.Y. Membrane-mediated fibrillation and toxicity of the tau hexapeptide PHF6. J. Biol. Chem. 2019, 294, 15304-15317. [CrossRef]

180. Maeda, S.; Sahara, N.; Saito, Y.; Murayama, S.; Ikai, A.; Takashima, A. Increased levels of granular tau oligomers: An early sign of brain aging and Alzheimer's disease. Neurosci. Res. 2006, 54, 197-201. [CrossRef]

181. Griner, S.L.; Seidler, P.; Bowler, J.; Murray, K.A.; Yang, T.P.; Sahay, S.; Sawaya, M.R.; Cascio, D.; Rodriguez, J.A.; Philipp, S.; et al. Structure-based inhibitors of amyloid beta core suggest a common interface with tau. eLife 2019, 8, e46924-e46952. [CrossRef]

182. Fitzpatrick, A.W.P.; Falcon, B.; He, S.; Murzin, A.G.; Murshudov, G.; Garringer, H.J.; Crowther, R.A.; Ghetti, B.; Goedert, M.; Scheres, S.H.W. Cryo-EM structures of tau filaments from Alzheimer's disease. Nature 2017, 547, 185-190. [CrossRef] [PubMed]

183. Falcon, B.; Zhang, W.; Murzin, A.G.; Murshudov, G.; Garringer, H.J.; Vidal, R.; Crowther, R.A.; Ghetti, B.; Scheres, S.H.W.; Goedert, M. Structures of filaments from Pick's disease reveal a novel tau protein fold. Nature 2018, 561, 137-140. [CrossRef] [PubMed]

184. Falcon, B.; Zivanov, J.; Zhang, W.; Murzin, A.G.; Garringer, H.J.; Vidal, R.; Crowther, R.A.; Newell, K.L.; Ghetti, B.; Goedert, M.; et al. Novel tau filament fold in chronic traumatic encephalopathy encloses hydrophobic molecules. Nature 2019, 568, 420-423. [CrossRef] [PubMed]

185. Goedert, M. Tau filaments in neurodegenerative diseases. FEBS Lett. 2018, 592, 2383-2391. [CrossRef]

186. La Joie, R.; Visani, A.V.; Baker, S.L.; Brown, J.A.; Bourakova, V.; Cha, J.; Chaudhary, K.; Edwards, L.; Iaccarino, L.; Janabi, M.; et al. Prospective longitudinal atrophy in Alzheimer's disease correlates with the intensity and topography of baseline tau-PET. Sci. Transl. Med. 2020, 12, 5732-5745. [CrossRef]

187. Guo, W.; Stoklund Dittlau, K.; Van Den Bosch, L. Axonal transport defects and neurodegeneration: Molecular mechanisms and therapeutic implications. Semin. Cell Dev. Biol. 2019, 99, 133-150. [CrossRef]

188. Violet, M.; Chauderlier, A.; Delattre, L.; Tardivel, M.; Chouala, M.S.; Sultan, A.; Marciniak, E.; Humez, S.; Binder, L.; Kayed, R.; et al. Prefibrillar Tau oligomers alter the nucleic acid protective function of Tau in hippocampal neurons in vivo. Neurobiol. Dis. 2015, 82, 540-551. [CrossRef]

189. Eftekharzadeh, B.; Daigle, J.G.; Kapinos, L.E.; Coyne, A.; Schiantarelli, J.; Carlomagno, Y.; Cook, C.; Miller, S.J.; Dujardin, S.; Amaral, A.S.; et al. Tau Protein Disrupts Nucleocytoplasmic Transport in Alzheimer's Disease. Neuron 2018, 99, 925-940. [CrossRef]

190. Chin, J.; Scharfman, H.E. Shared cognitive and behavioral impairments in epilepsy and Alzheimer's disease and potential underlying mechanisms. Epilepsy Behav. 2013, 26, 343-351. [CrossRef]

191. DeVos, S.L.; Goncharoff, D.K.; Chen, G.; Kebodeaux, C.S.; Yamada, K.; Stewart, F.R.; Schuler, D.R.; Maloney, S.E.; Wozniak, D.F.; Rigo, F.; et al. Antisense Reduction of Tau in Adult Mice Protects against Seizures. J. Neurosci. 2013, 33, 12887-12897. [CrossRef]

192. Gheyara, A.L.; Ponnusamy, R.; Djukic, B.; Craft, R.J.; Ho, K.; Guo, W.; Finucane, M.M.; Sanchez, P.E.; Mucke, L. Tau reduction prevents disease in a mouse model of Dravet syndrome: Tau Ablation in DS. Ann. Neurol. 2014, 76, 443-456. [CrossRef] [PubMed]

193. Tai, H.-C.; Wang, B.Y.; Serrano-Pozo, A.; Frosch, M.P.; Spires-Jones, T.L.; Hyman, B.T. Frequent and symmetric deposition of misfolded tau oligomers within presynaptic and postsynaptic terminals in Alzheimer's disease. Acta Neuropathol. Commun. 2014, 2, 146-160. [CrossRef] [PubMed]

194. Zempel, H.; Dennissen, F.J.A.; Kumar, Y.; Luedtke, J.; Biernat, J.; Mandelkow, E.-M.; Mandelkow, E. Axodendritic sorting and pathological missorting of Tau are isoform-specific and determined by axon initial segment architecture. J. Biol. Chem. 2017, 292, 12192-12207. [CrossRef] [PubMed]

195. Busche, M.A.; Wegmann, S.; Dujardin, S.; Commins, C.; Schiantarelli, J.; Klickstein, N.; Kamath, T.V.; Carlson, G.A.; Nelken, I.; Hyman, B.T. Tau impairs neural circuits, dominating amyloid- $\beta$ effects, in Alzheimer models in vivo. Nat. Neurosci. 2019, 22, 57-64. [CrossRef] [PubMed]

196. Terada, T.; Yokokura, M.; Obi, T.; Bunai, T.; Yoshikawa, E.; Ando, I.; Shimada, H.; Suhara, T.; Higuchi, M.; Ouchi, Y. In vivo direct relation of tau pathology with neuroinflammation in early Alzheimer's disease. J. Neurol. 2019, 266, 2186-2196. [CrossRef] [PubMed]

197. Vogels, T.; Murgoci, A.-N.; Hromádka, T. Intersection of pathological tau and microglia at the synapse. Acta Neuropathol. Commun. 2019, 7, 109-134. [CrossRef]

198. Pérez, M.; Avila, J.; Hernández, F. Propagation of Tau via Extracellular Vesicles. Front. Neurosci. 2019, 13, 698-705. [CrossRef] 
199. Dujardin, S.; Bégard, S.; Caillierez, R.; Lachaud, C.; Delattre, L.; Carrier, S.; Loyens, A.; Galas, M.-C.; Bousset, L.; Melki, R.; et al. Ectosomes: A New Mechanism for Non-Exosomal Secretion of Tau Protein. PLOS ONE 2014, 9, e100760. [CrossRef]

200. Vasili, E.; Dominguez-Meijide, A.; Outeiro, T.F. Spreading of $\alpha$-Synuclein and Tau: A Systematic Comparison of the Mechanisms Involved. Front. Mol. Neurosci. 2019, 12, 107-130. [CrossRef]

201. Lasagna-Reeves, C.A.; Castillo-Carranza, D.L.; Sengupta, U.; Guerrero-Munoz, M.J.; Kiritoshi, T.; Neugebauer, V.; Jackson, G.R.; Kayed, R. Alzheimer brain-derived tau oligomers propagate pathology from endogenous tau. Sci. Rep. 2012, 2, 700-707. [CrossRef]

202. Gibbons, G.S.; Lee, V.M.Y.; Trojanowski, J.Q. Mechanisms of Cell-to-Cell Transmission of Pathological Tau: A Review. JAMA Neurol. 2019, 76, 101-108. [CrossRef] [PubMed]

203. Franzmeier, N.; Rubinski, A.; Neitzel, J.; Kim, Y.; Damm, A.; Na, D.L.; Kim, H.J.; Lyoo, C.H.; Cho, H.; Finsterwalder, S.; et al. Functional connectivity associated with tau levels in ageing, Alzheimer's, and small vessel disease. Brain 2019, 142, 1093-1107. [CrossRef] [PubMed]

204. Hardy, J. The discovery of Alzheimer-causing mutations in the APP gene and the formulation of the "amyloid cascade hypothesis. "FEBS J. 2017, 284, 1040-1044. [CrossRef]

205. Di Fede, G.; Catania, M.; Morbin, M.; Rossi, G.; Suardi, S.; Mazzoleni, G.; Merlin, M.; Giovagnoli, A.R.; Prioni, S.; Erbetta, A.; et al. A Recessive Mutation in the APP Gene with Dominant-Negative Effect on Amyloidogenesis. Science 2009, 323, 1473-1477. [CrossRef]

206. Jonsson, T.; Atwal, J.K.; Steinberg, S.; Snaedal, J.; Jonsson, P.V.; Bjornsson, S.; Stefansson, H.; Sulem, P.; Gudbjartsson, D.; Maloney, J.; et al. A mutation in APP protects against Alzheimer's disease and age-related cognitive decline. Nature 2012, 488, 96-99. [CrossRef] [PubMed]

207. Ono, K.; Condron, M.M.; Teplow, D.B. Effects of the English (H6R) and Tottori (D7N) Familial Alzheimer Disease Mutations on Amyloid $\beta$-Protein Assembly and Toxicity. J. Biol. Chem. 2010, 285, 23186-23197. [CrossRef]

208. Obici, L.; Demarchi, A.; de Rosa, G.; Bellotti, V.; Marciano, S.; Donadei, S.; Arbustini, E.; Palladini, G.; Diegoli, M.; Genovese, E.; et al. A novelA $\beta P P$ mutation exclusively associated with cerebral amyloid angiopathy. Ann. Neurol. 2005, 58, 639-644. [CrossRef]

209. Stocker, H.; Möllers, T.; Perna, L.; Brenner, H. The genetic risk of Alzheimer's disease beyond APOE $\varepsilon 4$ : Systematic review of Alzheimer's genetic risk scores. Transl. Psychiatry 2018, 8, 166-175. [CrossRef]

210. Huynh, T.-P.V.; Davis, A.A.; Ulrich, J.D.; Holtzman, D.M. Apolipoprotein E and Alzheimer's disease: The influence of apolipoprotein E on amyloid- $\beta$ and other amyloidogenic proteins. J. Lipid Res. 2017, 58, 824-836. [CrossRef]

211. Holtzman, D.M.; Bales, K.R.; Tenkova, T.; Fagan, A.M.; Parsadanian, M.; Sartorius, L.J.; Mackey, B.; Olney, J.; McKeel, D.; Wozniak, D.; et al. Apolipoprotein E isoform-dependent amyloid deposition and neuritic degeneration in a mouse model of Alzheimer's disease. Proc. Natl. Acad. Sci. 2000, 97, 2892-2897. [CrossRef]

212. de Rojas, I.; Moreno-Grau, S.; Tesi, N.; Grenier-Boley, B.; Andrade, V.; Jansen, I.; Pedersen, N.L.; Stringa, N.; Zettergren, A.; Hernández, I.; et al. Common variants in Alzheimer's disease: Novel association of six genetic variants with $\mathrm{AD}$ and risk stratification by polygenic risk scores. Mol. Genet. Genom. Med. 2019. [CrossRef]

213. Sierksma, A.; Lu, A.; Mancuso, R.; Fattorelli, N.; Thrupp, N.; Salta, E.; Zoco, J.; Blum, D.; Buée, L.; De Strooper, B.; et al. Novel Alzheimer risk genes determine the microglia response to amyloid- $\beta$ but not to TAU pathology. EMBO Mol. Med. 2020, 12, e10606-e10624. [CrossRef] [PubMed]

214. van der Kant, R.; Goldstein, L.S.B.; Ossenkoppele, R. Amyloid- $\beta$-independent regulators of tau pathology in Alzheimer disease. Nat. Rev. Neurosci. 2020, 21, 21-35. [CrossRef] [PubMed]

215. Zheng, W.-H.; Bastianetto, S.; Mennicken, F.; Ma, W.; Kar, S. Amyloid $\beta$ peptide induces tau phosphorylation and loss of cholinergic neurons in rat primary septal cultures. Neuroscience 2002, 115, 201-211. [CrossRef]

216. Jin, M.; O’Nuallain, B.; Hong, W.; Boyd, J.; Lagomarsino, V.N.; O’Malley, T.T.; Liu, W.; Vanderburg, C.R.; Frosch, M.P.; Young-Pearse, T.; et al. An in vitro paradigm to assess potential anti-A $\beta$ antibodies for Alzheimer's disease. Nat. Commun. 2018, 9, 2676-2689. [CrossRef]

217. Sato, C.; Barthélemy, N.R.; Mawuenyega, K.G.; Patterson, B.W.; Gordon, B.A.; Jockel-Balsarotti, J.; Sullivan, M.; Crisp, M.J.; Kasten, T.; Kirmess, K.M.; et al. Tau Kinetics in Neurons and the Human Central Nervous System. Neuron 2018, 97, 1284-1298. [CrossRef] 
218. Hyman, B.T. Amyloid-Dependent and Amyloid-Independent Stages of Alzheimer Disease. Arch. Neurol. 2011, 68, 1062-1064. [CrossRef]

219. Stancu, I.-C.; Vasconcelos, B.; Terwel, D.; Dewachter, I. Models of $\beta$-amyloid induced Tau-pathology: The long and "folded" road to understand the mechanism. Mol. Neurodegener. 2014, 9, 51-65. [CrossRef]

220. He, Z.; Guo, J.L.; McBride, J.D.; Narasimhan, S.; Kim, H.; Changolkar, L.; Zhang, B.; Gathagan, R.J.; Yue, C.; Dengler, $C$; ; et al. Amyloid- $\beta$ plaques enhance Alzheimer's brain tau-seeded pathologies by facilitating neuritic plaque tau aggregation. Nat. Med. 2018, 24, 29-38. [CrossRef]

221. Shin, W.S.; Di, J.; Cao, Q.; Li, B.; Seidler, P.M.; Murray, K.A.; Bitan, G.; Jiang, L. Amyloid $\beta$-protein oligomers promote the uptake of tau fibril seeds potentiating intracellular tau aggregation. Alzheimers Res. Ther. 2019, 11, 86-99. [CrossRef]

222. Shin, W.S.; Di, J.; Murray, K.A.; Sun, C.; Li, B.; Bitan, G.; Jiang, L. Different Amyloid- $\beta$ Self-Assemblies Have Distinct Effects on Intracellular Tau Aggregation. Front. Mol. Neurosci. 2019, 12, 268-276. [CrossRef] [PubMed]

223. Pickett, E.K.; Herrmann, A.G.; McQueen, J.; Abt, K.; Dando, O.; Tulloch, J.; Jain, P.; Dunnett, S.; Sohrabi, S.; Fjeldstad, M.P.; et al. Amyloid Beta and Tau Cooperate to Cause Reversible Behavioral and Transcriptional Deficits in a Model of Alzheimer's Disease. Cell Rep. 2019, 29, 3592-3604. [CrossRef] [PubMed]

224. Ising, C.; Venegas, C.; Zhang, S.; Scheiblich, H.; Schmidt, S.V.; Vieira-Saecker, A.; Schwartz, S.; Albasset, S.; McManus, R.M.; Tejera, D.; et al. NLRP3 inflammasome activation drives tau pathology. Nature 2019, 575, 669-673. [CrossRef] [PubMed]

225. Jadhav, S.; Avila, J.; Schöll, M.; Kovacs, G.G.; Kövari, E.; Skrabana, R.; Evans, L.D.; Kontsekova, E.; Malawska, B.; de Silva, R.; et al. A walk through tau therapeutic strategies. Acta Neuropathol. Commun. 2019, 7, 22-53. [CrossRef]

226. Morsy, A.; Trippier, P.C. Current and Emerging Pharmacological Targets for the Treatment of Alzheimer's Disease. J. Alzheimers Dis. 2019, 72, S145-S176. [CrossRef]

227. Huang, L.-K.; Chao, S.-P.; Hu, C.-J. Clinical trials of new drugs for Alzheimer disease. J. Biomed. Sci. 2020, 27, 18-31. [CrossRef]

228. Cummings, J.; Lee, G.; Ritter, A.; Sabbagh, M.; Zhong, K. Alzheimer's disease drug development pipeline: 2019. Alzheimers Dement. Transl. Res. Clin. Interv. 2019, 5, 272-293. [CrossRef]

229. Hara, Y.; McKeehan, N.; Fillit, H.M. Translating the biology of aging into novel therapeutics for Alzheimer disease. Neurology 2019, 92, 84-93. [CrossRef]

230. Liang, C.; Savinov, S.N.; Fejzo, J.; Eyles, S.J.; Chen, J. Modulation of Amyloid- $\beta 42$ Conformation by Small Molecules Through Nonspecific Binding. J. Chem. Theory Comput. 2019, 15, 5169-5174. [CrossRef]

231. Hamlett, E.D.; Hjorth, E.; Ledreux, A.; Gilmore, A.; Schultzberg, M.; Granholm, A.C. RvE1 treatment prevents memory loss and neuroinflammation in the Ts65Dn mouse model of Down syndrome. Glia 2020, 1-14. [CrossRef]

232. Derakhshankhah, H.; Sajadimajd, S.; Jafari, S.; Izadi, Z.; Sarvari, S.; Sharifi, M.; Falahati, M.; Moakedi, F.; Muganda, W.C.A.; Müller, M.; et al. Novel therapeutic strategies for Alzheimer's disease: Implications from cell-based therapy and nanotherapy. Nanomed. Nanotechnol. Biol. Med. 2020, 24, 102149-102220. [CrossRef] [PubMed]

(C) 2020 by the authors. Licensee MDPI, Basel, Switzerland. This article is an open access article distributed under the terms and conditions of the Creative Commons Attribution (CC BY) license (http://creativecommons.org/licenses/by/4.0/). 